\section{The \\ University \\ of Chicago \\ Law Review}

- 1990 by The University of Chicago

\title{
Ineff ective Assistance and Procedural Default in Federal Habeas Corpus
}

\author{
John C. Jeffries, Jr.† and William J. Stuntz††
}

A defendant whose lawyer fails to raise a federal claim at trial in state court may sometimes, but not always, raise that claim on collateral review. If the mechanism of review is state created, its terms are set by state law. If the conviction is attacked in federal court, the law of federal habeas corpus governs access to review. ${ }^{1}$ The subject of this article is the law governing federal collateral review of claims not properly raised in state court.

That law is anything but simple. It is a piecemeal doctrinal construction, each part more readily explained by the circumstances of its addition than by its relation to a coherent whole. The cumulation of category and exception threatens to obscure the underlying objectives of federal habeas corpus and to oppress its administration. That reform is needed, few will doubt. But the appropriate direction of reform is hotly controverted. The disputes

† Emerson Spies Professor and John V. Ray Research Professor, the University of Virginia School of Law.

t† Professor, the University of Virginia School of Law. The authors wish to thank Richard Bonnie, Dennis Curtis, Earl Dudley, Pamela Karlan, Harold Krent, Peter Low, Daniel Meltzer, and Judith Resnik for their helpful comments on earlier drafts.

1 This remedy is provided by 28 USC $\$ 2254$ (1982). The analogous collateral remedy for federal trials is provided by 28 USC $\S 2255$ (1982). In important respects it parallels $\S 2254$. 
transcend mere questions of doctrine; they strike deep into fundamental disagreements about what federal collateral review should seek to do.

It would be vain to suppose that doctrinal reconstruction can altogether bridge such divisions or persuade those who find the premises of our argument uncongenial. Nevertheless, our purpose is to propose doctrinal reform of the requirements for federal collateral review of defaulted claims. We propose a radical simplification of existing doctrine so that it can focus more directly on the objectives we think habeas corpus, as distinct from direct review, should serve in this context. We hope thereby to reduce the inevitable distance between doctrine and policy and to present a coherent and plausible conception of the law in this field. Naturally, we also hope to attract support for this view.

Section I surveys existing law. This involves two bodies of doctrine that, although separate in origin and divergent in content, largely overlap. One is the line of cases, beginning with Wainwright v Sykes", that articulates "cause" and "prejudice" as requirements for federal habeas review of defaulted claims. The other involves the Sixth Amendment right of effective assistance of counsel, as that right is enforced on federal habeas. ${ }^{3}$ Because these doctrines cover much of the same ground, any plausible suggestion for reform must take account of both.

Section II explains our proposal. We reject the increasing proceduralization of habeas law and focus squarely on the substance of defaulted claims. The question, in our view, should be whether consideration of a defaulted claim would present a realistic possibility of correcting an unjust conviction or sentence of death. If so, procedural barriers should be swept aside and collateral review should be available. If not, the conviction or sentence should stand without "appellate" correction on collateral review of other trial errors. This reform would grant relief to those defendants who deserve it, deny relief to others, and would do so while simplifying the issues for lawyers and judges. Significantly, it would also go some distance toward eliminating the retroactivity issue that seems about to engulf habeas doctrine. Of course, the focus on innocence is not original with us. Twenty years ago, Henry Friendly suggested something similar for habeas corpus as a

2433 US 72 (1977).

s See Strickland $v$ Washington, 466 US 668 (1984). 
whole, ${ }^{4}$ and the concern for innocence is one of several strands that run through Supreme Court opinions. Yet we think a good deal more can be said for this view, particularly in the context of defaulted claims. Thus, Section II attempts to refine and defend that position. Section III presents illustrative cases. Finally, Section IV briefly examines certain related issues in the law of ineffective assistance of counsel.

\section{The Law of Procedural Default}

\section{A. Stated Generally}

A defendant whose lawyer fails to raise a claim at the time or in the manner required by state procedures may lose the chance to have that claim heard. Even if the claim is identified before appeal, the appellate court may stand on the procedural default and refuse to address the merits. Such refusal is permitted by federal law and ordinarily will be respected by the Supreme Court in the unlikely event of direct review. ${ }^{5}$ The same is true for claims properly raised at trial but not properly presented on appeal. Such default may justify the appellate court in refusing to hear the claim, and its refusal will also bar direct review by the Supreme Court.

Sometimes, however, the defendant ${ }^{b}$ can attack the default collaterally. This can be done in two ways. First, under Wainwright $v$ Sykes, the defendant can seek to undo the forfeiture by showing "cause" for the default and "prejudice" resulting from it." If these requirements are met, the federal court will consider the merits of the defaulted claim, and if it is sound and its omission not harmless, order a new trial (or, in a capital case, a new sentencing proceeding). Alternatively, the defendant can treat the lawyer's failure to raise the claim as an independent constitutional viola-

\footnotetext{
- Henry J. Friendly, Is Innocence Irrelevant? Collateral Attack on Criminal Judgments, $38 \mathrm{U}$ Chi L Rev 142 (1970).

- Of course, the procedures themselves must be constitutionally permissible and, in order to bar Supreme Court review, "adequate" and "independent" of federal law. A fair number of cases have found state procedural defaults inadequate to preclude Supreme Court review, but most mean less than they seem to say. See, for example, Williams v Georgia, 349 US 375, 383 (1955) (suggesting that a procedural default is not adequate to bar Supreme Court review if the state court had the power to overlook it). In most of these cases, the facts suggested bad faith manipulation of state procedures to defeat federal rights. See generally Peter W. Low and John C. Jeffries, Jr., Federal Courts and the Law of Federal-State Relations 614-56 (Foundation, 2d ed 1989). Since such manipulation surely must be rare, and in any event difficult to discern on direct review, Supreme Court findings of the inadequacy of state procedural grounds are very much the exception rather than the rule.

- For ease of exposition, habeas petitioners are referred to as "defendants."

7 Sykes, 433 US at 87-91.
} 
tion. Under Strickland $v$ Washington, the attorney's failure to raise a pertinent claim constitutes a denial of effective assistance of counsel if the error fell below a certain standard of attorney competence and likely affected the outcome of the prosecution. ${ }^{8}$

These two lines of attack are only partly convergent. Lawyer error constituting ineffective assistance of counsel is indisputably "cause" under Sykes, ${ }^{\circ}$ but only a small percentage of defaulted claims involve such error. Effective assistance of counsel ostensibly requires that the lawyer's conduct be "reasonable considering all the circumstances," 10 but the Court has emphasized that the Sixth Amendment claimant must overcome a "strong presumption" that the lawyer's conduct fell within professional norms. ${ }^{11}$ This means that any colorable reason for not raising a claim (viewing the lawyer's decision without benefit of hindsight) ${ }^{12}$ defeats a defendant's later assertion of a Sixth Amendment violation based on that default. In practice, the constitutional standard for ineffective assistance of counsel approximates gross negligence.

Given this standard, it is less important that ineffective assistance is "cause" than that most other attorney error is not. Ordinary oversight, simple miscalculation, bad judgment-none constitutes "cause" for failure to raise a constitutional claim. ${ }^{13}$ There is a category of "cause" arising from wholly non-negligent error-failure to raise a claim the basis for which was created by a subsequent change in the law ${ }^{14}$-but this category is narrowly confined ${ }^{15}$ and in any event inapplicable if a new pronouncement does

466 US 668, 687-96 (1984).

- See Murray v Carrier, 477 US 478, 488 (1986).

10 Strickland, 466 US at 688.

12 Id at 689-91.

12 Id at 689 ("A fair assessment of attorney performance requires that every effort be made to eliminate the distorting effects of hindsight, to reconstruct the circumstances of counsel's challenged conduct, and to evaluate the conduct from counsel's perspective at the time.").

is See, for example, Carrier, 477 US at 486-88; and Smith v Murray, 477 US 527, 53436 (1986).

${ }^{14}$ Reed $v$ Ross, 468 US 1, 13-16 (1984).

${ }^{15}$ See Engle $v$ Isaac, 456 US 107, 130-34 (1982). The defaulted claim in Engle was that the jury instructions unconstitutionally shifted to the defendant the burden of proof on selfdefense. The trial occurred after In re Winship, 397 US 358 (1970) (establishing a constitutional requirement of proof beyond a reasonable doubt in criminal cases), but before the Court had applied Winship to overturn rules shifting the burden of proof on some grading elements, see Mullaney v Wilbur, 421 US 684 (1975), or on intent generally, see Sandstrom v Montana, 442 US 510 (1979). The Engle Court stated that "dozens" of defense lawyers had challenged similar instructions by the time of the defendant's trial, but acknowledged that such challenges "countered well-established principles of law." 456 US at 131-32. It 
not apply retroactively. ${ }^{16}$ (This category is necessary to allow retroactive application of new rulings; otherwise, no institutional apparatus would exist for implementing fully retroactive decisions.) Additionally, "cause" will be found where a claim was not raised due to "some objective factor external to the defense"17 (not merely to the defendant), such as government misconduct that suppresses facts giving rise to the claim. ${ }^{18}$ But these rare cases aside, "cause" for failing to raise a claim exists only where the misjudgment or oversight amounts to an independent constitutional violation under the Sixth Amendment, and the mistake must be truly egregious to violate this standard.

The upshot of all this is easy to state, but hard to justify: criminal defendants are often bound by the mistakes of their lawyers. This might be tolerable if the stakes were less high, but the prospect of defendants sitting in jail because of attorney error is at least unsettling. This is the chief objection to both Sykes ${ }^{19}$ and Strickland, ${ }^{20}$ at least among academics. Their proposed remedies also are parallel. "Cause" should be defined more expansively, along the lines of the deliberate bypass standard of Fay $v$ Noia. ${ }^{21}$

found the fact that some defense counsel had made such arguments enough to preclude a finding of "cause" for failure to do so.

16 See Allen v Hardy, 478 US 255 (1986) (per curiam) (holding that the rule of Batson v Kentucky, 476 US 79 (1986), should not be applied retroactively on federal habeas to convictions that became final before Batson was announced); see also Teague $v$ Lane, $109 \mathrm{~S} \mathrm{Ct}$ 1060 (1989) (plurality opinion) (concluding that rules that cannot be applied retroactively on federal habeas cannot be announced on federal habeas); and Penry $v$ Lynaugh, $109 \mathrm{~S} \mathrm{Ct}$ 2934, 2944-47 (1989) (adopting Teague plurality's analysis and applying it to rules governing the imposition of capital punishment).

17 Carrier, 477 US at 488.

1s See, for example, Amadeo $v$ Zant, 486 US 214 (1988).

19 See, for example, Robert M. Cover and T. Alexander Aleinikoff, Dialectical Federalism: Habeas Corpus and the Court, 86 Yale L J 1035, 1100-02 (1977); Barry Friedman, A Tale of Two Habeas, 73 Minn L Rev 247 (1988); Graham Hughes, Sandbagging Constitutional Rights: Federal Habeas Corpus and the Procedural Default Principle, 16 NYU Rev I \& Soc Change 321, 332 (1987-88); Daniel J. Meltzer, State Court Forfeitures of Federal Rights, 99 Harv L Rev 1128, 1215-18 (1986); Yale L. Rosenberg, Jettisoning Fay v. Noia: Procedural Defaults by Reasonably Incompetent Counsel, 62 Minn L Rev 341, 425 (1978); and Peter W. Tague, Federal Habeas Corpus and Ineffective Representation of Counsel: The Supreme Court Has Work to Do, 31 Stan L Rev 1, 67 (1978).

${ }_{20}$ See, for example, Vivian O. Berger, The Supreme Court and Defense Counsel: Old Roads, New Paths-A Dead End?, 86 Colum L Rev 9, 81-100 (1986); Gary Goodpaster, The Adversary System, Advocacy, and Effective Assistance of Counsel in Criminal Cases, 14 NYU Rev L \& Soc Change 59, 67 (1986); Richard Klein, The Emperor Gideon Has No Clothes: The Empty Promise of the Constitutional Right to Effective Assistance of Counsel, 13 Hastings Const L Q 625, 640-45 (1986).

21372 US 391, 438 (1963) (holding that the independent and adequate state ground doctrine does not limit the scope of federal habeas corpus jurisdiction, and that a federal court has discretion to deny relief only where an applicant "has deliberately by-passed the 
Similarly, ineffective assistance of counsel should be expanded to cover a wider range of merely negligent mistakes. ${ }^{22}$ In these suggestions, the critics share the Court's approach, if not its conclusions. They would continue to inquire into the reason for a default in order to assess its enforceability. ${ }^{23}$ The differences lie chiefly in the showings that would suffice.

If the defendant can show Strickland ineffectiveness or other Sykes "cause," the court's attention then turns to "prejudice." Here, too, habeas and Sixth Amendment doctrine converge, for both require a showing of "prejudice." The term means some likelihood-greater than that sufficient to create a reasonable doubt but perhaps less than "more likely than not"-that the error or default affected the outcome of the prosecution. Strickland expresses the idea this way:

The defendant must show that there is a reasonable probability that, but for counsel's unprofessional errors, the result of the proceeding would have been different. A reasonable probability is a probability sufficient to undermine confidence in the outcome. ${ }^{24}$

The Court has not expressly adopted this test for the "prejudice" prong of Sykes, but its opinions suggest something very similar. ${ }^{25}$

orderly procedure of the state courts"). See, for example, Meltzer, 99 Harv L Rev at 1215-22 (cited in note 19) (arguing for a deliberate bypass standard, with conscious decisions by defense counsel counting as deliberate bypass); Tague, 31 Stan L Rev at 38-56 (cited in note 19) (arguing that the Court should have limited the scope of claims that can be raised on federal habeas instead of enforcing procedural defaults).

${ }^{22}$ See, for example, sources cited in note 20 . This argument is often coupled with the suggestion that the prejudice requirement be scrapped. See, for example, Berger, 86 Colum $\mathrm{L}$ Rev at 89-100 (cited in note 20). The critics who argue for a broader conception of ineffectiveness and abandonment of the prejudice requirement largely endorse the position taken by Justice Marshall in his Strickland dissent. 466 US at 707-15 (Marshall dissenting).

${ }_{23}$ Two notable exceptions are Jack A. Guttenberg, Federal Habeas Corpus, Constitutional Rights, and Procedural Forfeitures: The Delicate Balance, 12 Hofstra L Rev 617, 702-14 (1984); and Comment, Effective Assistance of Counsel: The Sixth Amendment and the Fair Trial Guarantee, 50 U Chi L Rev 1380, 1419-29 (1983). Professor Guttenberg reaches a conclusion close to ours-we should say ours is close to his-but the structure of the arguments is different and, in at least one important respect, we reach a different result. Compare Guttenberg, 12 Hofstra L Rev at 716-17 (arguing that courts should categorize constitutional protections as guilt-related or not) with text at notes 48-49 (suggesting that such categorization is both difficult and unnecessary).

${ }^{24}$ Strickland, 466 US at 694.

${ }^{25}$ See United States v Frady, 456 US 152, 168-69 (1982), which, like Strickland, defines "prejudice" in terms that avoid both the conventional harmless-beyond-a-reasonabledoubt standard and the more-likely-than-not outcome determinative test. Both Frady and Strickland link "reasonable probability" of affecting outcome with due process notions of fundamental fairness. Compare Frady, 456 US at 169, quoting Cupp v Naughten, 414 US 
Note the nature of this standard. All agree that errors harmless beyond a reasonable doubt do not require reversal of a conviction, whether on direct appeal or collateral review. This simply recognizes the futility of a search for perfection. But the Court's "reasonable probability" standard of prejudice requires a much higher likelihood of effect on the outcome than the mere possibility of reasonable doubt. Moreover, the "reasonable probability" standard applies to errors of all sorts. An omitted claim that has less than a "reasonable probability" of affecting the outcome is barred, whether it concerns factual guilt or merely the enforcement of a prophylactic rule. The outcome-oriented definition of "prejudice" thus treats the possibility of a factually erroneous conviction and the possibility of mistaken nonenforcement of a prophylactic rule as equally (non)serious.

An obvious alternative is to shift the focus from the likelihood of effect on the outcome to the kind of effect that should matter. "Prejudice" could be used to differentiate among defaulted claims according to their impact on guilt. This approach would restrict collateral review of defaulted claims, but in a different way from the indiscriminate requirement of heightened likelihood of an effect on outcome, as reflected in the definition of "reasonable probability."

The Supreme Court has toyed with this approach, but its pronouncements to date are mixed and inconclusive. It has supported a safety valve exception to the requirement of "cause." Where procedural default has "probably resulted in the conviction of one who is actually innocent," habeas relief is available without regard to the nature of the lawyer's error. ${ }^{28}$ This willingness to overlook

141,147 (1973) (the habeas "prejudice" standard is "whether the ailing instruction by itself so infected the entire trial that the resulting conviction violates due process"), with Strickland, 466 US at 696 ("the ultimate focus of inquiry must be on the fundamental fairness of the proceeding whose result is being challenged").

Despite these parallels, the matter is sufficiently unclear that some argue that the two "prejudice" standards differ. See James S. Liebman, Federal Habeas Corpus Practice and Procedure \$ 24.5(d) at 357-58 (Michie, 1988) (suggesting that Sykes prejudice is "consistent with traditional harmless error analysis"); and Maria L. Marcus, Federal Habeas Corpus After State Court Default: A Definition of Cause and Prejudice, 53 Fordham L Rev 663, 701-03 (1985) (arguing that Sykes "prejudice" is actually more stringent than Strickland "prejudice").

26 Carrier, 477 US at 495-96, quoting Engle $v$ Isaac, 456 US 107, 135 (1982):

"[A]s we [] noted in Engle, '[i]n appropriate cases' the principles of comity and finality that inform the concepts of cause and prejudice 'must yield to the imperative of correcting a fundamentally unjust incarceration.' ... . We remain confident that, for the most part, 'victims of a fundamental miscarriage of justice will meet the cause-andprejudice standard.' . . . But we do not pretend that this will always be true. Accord- 
"cause" to avoid a "miscarriage of justice" is welcome, but the Court's accommodation is only partial, for the exception applies only to the "extraordinary" case where the showing of actual innocence rises to the required level of probability. ${ }^{27}$ Nevertheless, the "miscarriage of justice" exception does indicate, in partial answer to Henry Friendly, that innocence is not altogether irrelevant in habeas review. ${ }^{28}$

On the Sixth Amendment side, the Court's interest in innocence as the criterion of "prejudice" has been even less consistent. In Nix $v$ Whiteside, ${ }^{29}$ the Court rejected the ineffective assistance claim of a defendant deterred from committing perjury by his lawyer's threat to disclose the falsehood. Whiteside is famous for the Court's endorsement of the lawyer's aggressive steps to prevent client perjury. ${ }^{30}$ Less attention has been paid to the gloss Whiteside seemed to place on Sixth Amendment "prejudice." All nine Justices concluded that, even if defense counsel acted incompetently and even if that action had the requisite effect on outcome, counsel's behavior still would not have been prejudicial. The reason was apparently that perjury is criminal conduct that detracts from the reliability of judgments. ${ }^{31}$ If the right to effective assistance of counsel aims to promote reliable outcomes, then any effect on outcome flowing from the Whiteside lawyer's threat to expose perjury would not count for Sixth Amendment purposes. As Justice Blackmun put it, "this Court must ask whether its confidence in the outcome of Whiteside's trial is in any way undermined by the knowledge that he refrained from presenting false testimony." ${ }^{2}$ The obvious answer was no.

Whiteside suggested that some errors affecting outcome cannot establish Strickland "prejudice" (or, by hypothesis, Sykes "prejudice"), and that the kind of errors that do not count are

ingly, we think that in an extraordinary case, where a constitutional violation has probably resulted in the conviction of one who is actually innocent, a federal habeas court may grant the writ even in the absence of showing of cause for the procedural default." Accord Harris v Reed, 109 S Ct 1038, 1043 (1989); and Smith v Murray, 477 US 527, 537 (1986).

27 Carrier, 477 US at $495-96$.

${ }^{28}$ Friendly, $38 \mathrm{U}$ Chi L Rev 142 (cited in note 4).

28475 US 157 (1986).

so Id at 174-75. See Brent R. Appel, The Limited Impact of Nix v. Whiteside on Attorney-Client Relations, $136 \mathrm{U} \mathrm{Pa}$ L Rev 1913 (1988); Monroe H. Freedman, Client Confidences and Client Perjury: Some Unanswered Questions, 136 U Pa L Rev 1939 (1988); and Patrick R. Grady, Nix v. Whiteside: Client Perjury and the Criminal Justice System: The Defendant's Position, 23 Am Crim L Rev 1 (1985).

s1 475 US at 175-76; id at 184-88 (Blackmun concurring).

32 Id at 185 (Blackmun concurring). 
those that do not affect the factual reliability of the determination of guilt. This reading was undercut, however, later that Term in Kimmelman $v$ Morrison..$^{33}$ Neil Morrison was convicted of rape in state court, based in part on laboratory tests of a bedsheet that had been seized, apparently illegally, from his apartment. ${ }^{34}$ Morrison's lawyer had failed to file a timely motion to suppress the bedsheet and lab reports. Federal habeas review of the Fourth Amendment claim was barred by Stone $v$ Powell, which held that a Fourth Amendment claim can be raised on federal habeas review only where there was not a full and fair opportunity to have the claim heard in state court. ${ }^{36}$ Morrison therefore pursued a Sixth Amendment claim, arguing that his lawyer had been ineffective in failing to raise this issue.

The Court unanimously found that Stone $v$ Powell did not bar the Sixth Amendment claim, even though it was based on default of a Fourth Amendment objection. The Justices further found that the lawyer's performance fell below standards of professional competence, but they divided over the kind of "prejudice" that Morrison had to show. Justice Brennan's majority opinion looked for a "reasonable probability" of effect on outcome: if there was a reasonable likelihood that his counsel's incompetence affected the outcome of the prosecution, Morrison was entitled to habeas relief. ${ }^{36}$ Justice Powell, writing for himself and two others, looked for an effect on innocence. Powell argued that the right to effective assistance of counsel was designed to prevent unjust outcomes and that the attorney's error in no way rendered the conviction unjust. ${ }^{37}$ Powell nevertheless voted to grant relief on the ground that the state had not raised the issue of Strickland "prejudice." For the same reason, he maintained that the Court's opinion should not be read to foreclose an innocence-based conception of "prejudice," although the majority's language seemed to do just that. $^{38}$

33477 US 365 (1986).

34 Id at 368-69. The seizure was warrantless, but it was not clear whether exigent circumstances were present. No court had ruled on the legality of the search when the Supreme Court decided the case.

s5 428 US 465 (1976).

s6 477 US $365,379-80,391$ (1986). The Court did not apply this test itself but remanded the case to the lower courts.

37 Id at 394-97 (Powell concurring in the judgment).

3s Id at 397-98 (Powell concurring in the judgment). Compare id at 380 (majority statement that "we decline to hold either that the guarantee of effective assistance of counsel belongs solely to the innocent or that it attaches only to matters affecting the determination of actual guilt"). 
Whiteside and Kimmelman are hard to reconcile. Both cases dealt with lawyer acts that enhance, rather than undermine, one's confidence in the factual accuracy of the convictions. In Whiteside, that fact seems to have convinced the Court that the lawyer's conduct, even if incompetent, did not merit remedy. In Kimmelman, the Court reached the opposite conclusion. ${ }^{39}$ Kimmelman is also in obvious tension with Stone $v$ Powell, and for the same reason. Stone precludes federal habeas review of Fourth Amendment claims because they do not undermine the finding of guilt; Kimmelman allows the defendant to make an end-run around Stone by recharacterizing a defaulted Fourth Amendment claim as a Sixth Amendment violation. Under Kimmelman, Sixth Amendment "prejudice" is shown by an effect on outcome, even if, as on the facts of that case, it actually increases the factual reliability of the conviction.

\section{B. An Illustrative Application}

The preceding discussion states the law, but it gives scant flavor of the elaborate decisionmaking required of federal habeas courts in procedural default cases. To get some idea of the operational complexity of these doctrines (and of certain related matters that we have not recounted fully), we suggest the following hypothetical.

Imagine a defendant whose lawyer fails to move to suppress an arguably involuntary confession until the beginning of the trial. The state has a rule requiring that such motions be made before trial but allowing trial courts to consider late motions on a discretionary basis. ${ }^{40}$ The trial judge decides that the motion should not be heard, both because there is no excuse for the untimeliness and because, in any event, "the confession plainly appears to be voluntary." After conviction and appeal, the defendant seeks federal habeas corpus. He seeks both to have the habeas court determine the voluntariness of his confession and to attack his lawyer's failure to raise that issue as ineffective assistance of counsel. How would a federal district judge (or magistrate) dedicated to implementing Supreme Court decisions proceed in this case?

39 The leading treatise endorses Kimmelman's position. See Wayne LaFave and Jerold H. Israel, 2 Criminal Procedure $\S 11.10$ (d) at 50 (West, Supp 1989).

to Rules providing for court discretion to consider late suppression motions are common. See, for example, Colo R Crim P 41(g) (1984); Conn Gen Stat Ann § 54-33f(b) (West, 1985); Fla $R$ Crim P 3.190(i) (West, 1973). 
With respect to the confession's voluntariness, the first issue is whether the trial judge's statement of the grounds for decision satisfied the required plain statement of reliance on the procedural default, or whether the claim was "really" decided on the merits. ${ }^{41}$ If the state court addressed the merits, the federal court should do likewise. If the state court did not reach the merits, the next issue is whether the state's procedural requirement was fairly applied. This resolves into the question of whether the state court's discretion to consider late claims vitiated the requirement that claims be timely made. If procedural foreclosure ordinarily was not invoked in such cases, the federal habeas court should address the merits. ${ }^{42}$ If such defaults were routinely enforced, the court should proceed to the Sykes test of "cause" and "prejudice."

Was there "cause" for the default, apart from the lawyer's alleged ineffectiveness? Conceivably so, if the defendant could show "some objective factor external to the defense" that would have prevented the attorney from recognizing the claim and raising it in a timely fashion; ${ }^{43}$ otherwise not, as there was no colorable claim of "new law." If "cause" is found, the court should inquire into whether the claim of involuntariness had a "reasonable probability" of affecting the outcome. If "cause" is not found, the court should ask whether failure to consider the involuntariness claim would "probably" result in the continued incarceration of one who is "actually innocent." 44

There is a second progression of issues for the ineffective assistance claim (and for ineffective assistance as the most likely form of Sykes "cause"). Did the attorney's failure to move to suppress fall below minimal standards of professional competence? This question may be troublesome, as it requires estimation of the apparent strength of such a motion at the time filing was required, given the information then available to counsel..5 If ineffective assistance is found, the court should inquire (as above) into the "rea-

4 See Harris v Reed, 109 S Ct 1038 (1989).

12 See, for example, Ulster County Court v Allen, 442 US 140, 147-54 (1979).

43 The quoted language comes from Carrier, 477 US at 488. Amadeo $v$ Zant, 486 US 214 (1988), provides an example of such an "objective factor"; the state suppressed information that could have supported a claim that the defendant's grand jury and petit jury were discriminatorily selected.

14 Carrier, 477 US at 496. Accord, Harris, $109 \mathrm{~S} \mathrm{Ct}$ at 1043.

${ }^{45}$ See Strickland, 466 US at $689-90$, on the importance of avoiding hindsight when assessing the competence of an attorney's acts. 
sonable probability" of the mistake affecting the outcome. If ineffective assistance is not found, the court should deny relief. ${ }^{46}$

This fairly simple example makes an obvious point: the decision tree for habeas review of defaulted claims is intricate and costly. To be sure, in many cases, the issues raised in the preceding paragraphs will be easy. Often, "cause" and "prejudice" are plainly absent, and the court can dispose of the petition without great effort. But many of these issues require intricate analysis and present opportunities for error. Most importantly, those legal issues seem largely unrelated to the merits of the defendant's claim. This is surely the greatest vice of the current system. Cases like the hypothetical discussed above are analyzed and resolved without any serious attention to whether the defendant's claim is one that warrants relief. 47

In essence, Sykes and Strickland require habeas lawyers and federal judges and magistrates to work through the equivalent of a law school exam every time a defendant tries to escape procedural default. We mean no disrespect to those who labor in this field when we voice the suspicion that most do not routinely track the ins and outs of this progression. In practice, federal habeas review may well be more direct, more casual, less preoccupied with the procedural preliminaries of habeas corpus, and more responsive to the court's perception (perhaps very quickly attained) of the merits of the claim. All this may be true. It may even be true that, despite the aesthetic sensibilities of academics and the sympathetic frustration of their students, habeas review achieves generally reasonable results. But even if such speculation were verified, it would not justify complacency about the law of procedural foreclosure, for it cannot be a very great recommendation of existing law that it works tolerably well when largely ignored.

\footnotetext{
18 A further puzzle is whether the exhaustion requirement demands that the defendant have presented his ineffective assistance claim to any then-available state court. The Court seems to have said that exhaustion is required whether the defendant is raising ineffective assistance as an independent claim or as Sykes "cause" for a procedural default. See Carrier, 477 US at 488-89. If that is so, the adjudication of defaulted claims involves yet another layer of complication.

47 The question of effective assistance of counsel is not a close proxy for the question of the merits of the claim because the court is only to consider what the lawyer knew (or should have known) at the time the claim was defaulted. The lawyer's reasonable assessment at the time and the actual merits of the claim (as judged by hindsight) are potentially very different issues.
} 


\section{Reforming Habeas Review of Defaulted Claims}

We favor reorienting habeas review of defaulted claims toward protection of the arguably innocent. This means that defendants should have easy access to habeas review where consideration of the defaulted claim might correct an unjust conviction (or sentence of death), but not otherwise. Such an approach would be both more and less restrictive than existing law. It would be more restrictive in that it would limit Sykes and Strickland "prejudice" to those omissions that impair the reliability of the finding of guilt. Where, as in Kimmelman, a default only enhances the reliability of a conviction, it would not be set aside on habeas corpus. At the same time, our approach would be less restrictive than existing law in that we would junk the requirement of "cause." We would not undertake to characterize the lawyer's error as competent, incompetent, negligent, non-negligent, or whatever. We would ask simply whether the error might have caused an unjust result. If so, we would grant habeas relief despite the absence of "cause"; if not, we would deny review despite effect on outcome.

Our focus is on factual innocence. By that phrase, we mean to include anyone who did not commit the crime with which he or she is charged. This includes defendants who are guilty of some crime but not the offense charged. In other words, factual innocence comprehends both the fact and grade of criminal liability. Of course, the "facts" supporting criminal liability are really findings or conclusions reached by the trier of fact, although we hope these conclusions closely correspond to real-world events. A claim suggesting "factual innocence" is, therefore, one that, if heard by the trier of fact, would militate with some appreciable force against the findings or conclusions needed to support criminal liability.

The arguable innocence standard can be expressed in many ways. The approach closest to the Court's own language would require the defendant to show a "reasonable probability" that the procedural default resulted in an erroneous conviction. We prefer "reasonable possibility" because it avoids the implication that factual innocence need be more likely than not. If relief were to be granted only on proof of actual probability of innocence, the Court's "miscarriage of justice" exception to "cause" would be sufficient. In our view, however, refusal to consider a defaulted claim is objectionable if there is any significant prospect of a factually erroneous conviction (or an unjustified sentence of death) resulting from that default. We think that that is true where the prospect of erroneous conviction is distinctly less than probable. At the same 
time, we do not mean to endorse habeas review of claims whose supposed benefit to the defendant is fanciful or remote. We suggest the phrase "reasonable possibility" to capture this combination of leniency and realism.

This approach obviously resembles Henry Friendly's suggestion, delivered with characteristic elegance and force, that habeas relief be limited to those petitioners who can make a colorable showing of factual innocence. Our proposal for defaulted claims also resembles the approach taken by the Supreme Court in Stone $v$ Powell, which barred most habeas review of Fourth Amendment claims based on the non-guilt-related character of those claims. ${ }^{48}$ But while the thrust of all these models is to take innocence into account on federal habeas review, the approaches differ in implementation. Judge Friendly's standard apparently would allow litigation of non-guilt-related claims in cases that, for reasons unrelated to those claims, were close on the merits. ${ }^{49}$ Stone, on the other hand, seems to require the categorization of constitutional claims in the abstract as guilt-related or not-a task that is particularly problematic for those constitutional rights that may protect innocence in some contexts but not others.

Asking whether the default raised a reasonable possibility of an unjust conviction avoids both difficulties. Defendants would not automatically be permitted to relitigate the merits of the charges against them by virtue of having, for example, a legally plausible defaulted Fourth Amendment claim. And there would be no need to decide, as a categorical matter, whether a given constitutional right protects innocence or some other cluster of interests; the is-

48428 US 465 (1976).

19 See Friendly, 38 U Chi L Rev 142 (cited in note 4). In other words, Judge Friendly would reopen claims on federal habeas corpus that we would not. Consider, for example, two rape cases. In both the evidence could have supported either conviction or acquittal; in both the defendants were convicted in part on judgments as to credibility. Also, consent was the only issue in both cases; intercourse was established by laboratory analysis of a bedsheet from the defendant's apartment. In case one, the bedsheet was illegally seized, but defense counsel failed to move to suppress it. In case two, the bedsheet was obtained lawfully.

As we read Judge Friendly, he would allow relitigation of the defaulted claim in case one. We would not because, from the standpoint of remedying injustice, the two cases should be treated the same. Both defendants were convicted in close cases, meaning that either defendant could have made a colorable showing of innocence. The fact that the defendant in case one has a plausible Fourth Amendment claim has nothing to do with that showing, since the bedsheet did not in any way undermine the accuracy of the jury's determination. On the contrary, it properly focused the jury's attention on consent, the only real question in the case. Unless one is prepared to relitigate all cases in which the factual judgment at trial was a close one, one should not grant relief because of the procedural default in such a case. 
sue would be reduced to whether innocence is plausibly at stake in the particular case at hand.

More importantly, Stone and Judge Friendly propose solutions to the general problem of how to allocate federal habeas relief. The premise of their proposals is that, for the most part, habeas corpus relief should aim to rectify particular injustices, and not (for example) to deter inattention to federal law on the part of recalcitrant state judges. We generally agree with that premise, but-and this is important-our proposal does not depend on it. No matter what one's approach to allocating habeas relief generally, there is no good argument against focusing on innocence when dealing with defaulted claims.

The test proposed here at least has the virtues of simplicity and directness. The real issue is not whether our test would simplify habeas review, but whether it would improve it. A "reasonable possibility" of innocence standard is about as economical and uncomplicated as any legal standard is likely to be. The question is whether it is also right.

\section{A. The Affirmative Argument}

It is easy to argue for using habeas review to protect against injustice. No habeas petitioner evokes more sympathy than one who can show a reasonable possibility of innocence based on procedural default. In such a case, there is a colorable showing that procedural error caused the administration of justice to go fundamentally wrong. A proper regard for the relative values at stake demands that we forgive the procedural default. This is not to say that the state's interests in the integrity of its procedures and in the finality of its judgments are trivial. It is only to say that those values are not absolute; they should give way to the imperative of correcting injustice. We think this simple statement a sufficient explanation of the grounds for habeas review of defaulted claims where there is a reasonable possibility of innocence. In our view, it also applies to the analogous case of a prisoner sentenced to death who can show a reasonable possibility of a factually unjustified sentence. It is unthinkable to send a defendant to execution without considering such a claim.

\section{B. The Negative Argument}

The hard part of the argument is to show that habeas review of defaulted claims should be unavailable when the default does not undermine the factual reliability of the conviction. Kim- 
melman $v$ Morrison is an example. ${ }^{30}$ There the lawyer's failure to raise the Fourth Amendment claim likely had a decisive effect on outcome, ${ }^{51}$ but did not conceivably affect the reliability of the conviction. At trial, the defendant claimed that he and the victim had not had sexual relations. The bedsheet and lab reports that were admitted into evidence, but that might have been excluded had the lawyer objected, tended to confirm the falsity of the defendant's claim. ${ }^{\text {s2 }}$ It is our view-contrary to the prevailing opinion among academics and to much of the Court's current doctrine-that such defaults should not be undone on federal habeas review.

In part, this view rests on the state's legitimate interest in the finality of its criminal judgments. Federal habeas review, which comes only after one (and often two) full rounds of litigation, should not be equated with the first-line appellate function of correcting all errors. Finality of judgments is an important value, as is confirmed by the law's regard for civil judgments. For all the reasons identified by Paul Bator-conservation of judicial resources, maintenance of a sense of importance and responsibility associated with the criminal trial, the need to avoid sending mixed signals about the defendant's punishment or rehabilitation, and avoidance of the institutional paralysis that flows from leaving decisions always open to challenge-criminal convictions, once obtained and affirmed on appeal, should not be lightly set aside. ${ }^{53}$ This is not to say that direct review should be similarly restricted. On the contrary, it is to assert a distinction between direct and collateral review in terms of the kinds of problems that resources should be used to correct.

These concerns are greatly bolstered if, as Justice Stevens has surmised ${ }^{54}$ the fact that a claim was not raised at trial suggests its irrelevance. Massaged by a trained advocate, a given set of facts may yield a great many constitutional claims. Some are obvious and central to the case; others are inventive long-shots. Like Jus-

so 477 US 365 (1986).

s2 See Morrison v Kimmelman, 650 F Supp 801, 809 (D NJ 1986) (on remand) (concluding that the failure to suppress the bedsheet "dramatically affected the evidentiary picture in this case").

${ }^{32}$ See id at 808-09.

ss Paul M. Bator, Finality in Criminal Law and Federal Habeas Corpus for State Prisoners, 76 Harv L Rev 441, 451-53 (1963).

s. See Engle $v$ Isaac, 456 US at $136 \mathrm{n} 1$ (Stevens concurring in part and dissenting in part); Rose $v$ Lundy, 455 US 509, $547-48$ n 17 (1982) (Stevens dissenting); Carrier, 477 US at $506 \mathrm{n} 13$ (Stevens concurring in the judgment); and Wainwright $v$ Sykes, 433 US 72, 9697 (1977) (Stevens concurring). 
tice Stevens, we suspect that even marginally competent lawyers ordinarily raise those claims that the facts most nearly support. The claims most likely to go unmentioned are those that are legally remote or factually fanciful. It seems likely, therefore, that successive habeas petitions based on defaulted claims will be increasingly occupied with the chaff of constitutional argumentation. ${ }^{.5}$ Of course, the occasional exception is precisely the point of habeas review, but the probabilities involved are certainly relevant in assessing the state's interest in the finality of convictions. ${ }^{56}$

In addition to its proper interest in finality, the state has a significant interest in enforcing the procedural rules that give rise to defaults. States have good and legitimate reasons for requiring timely presentation of claims; an orderly adjudicative process depends on such requirements. It is wasteful to wait until trial to decide whether the key piece of government evidence is admissible, and also wasteful to have a second round of review because the litigant did not raise the winning claim on the first appeal. These concerns are no makeweight. Critics of the procedural default doctrine argue that "mere" timing rules are not important enough to justify precluding constitutional claims, yet virtually no one argues that such timing rules should be dispensed with in federal practice. ${ }^{57}$ Surely if federal courts are entitled to insist on routine compliance with sensible procedures in their own trials, state courts should also be entitled to do so.

ss This may also explain why federal courts are usually content to screen habeas petitions with rather cursory procedures. See 28 USC § 2254 Rule 4 (1982) (authorizing such a process).

so An additional concern might, at least in theory, augment the state's interest in finality. Defense lawyers might abuse federal habeas corpus by intentionally defaulting on their federal claims in state court in order to save them for subsequent federal review. The occurrence of such "sandbagging" is hard to disprove, but we doubt its frequency. Defendants have strong and obvious incentives to seek state court adjudication of their federal claims, even if review is automatically available on federal habeas. Other things being equal, two bites at the apple are better than one. Also, federal habeas review will be long delayed, forcing the defendant to serve much of his sentence before obtaining relief. Even for claims challenging death sentences, where the last factor is not relevant, the defendant loses the opportunity to have his claim heard by state trial and appellate courts, on state collateral review as well as on direct appeal. Finally, the usual incentives to raise constitutional claims must be strongest when the claims are guilt-related, and those are the claims for which we would ignore attorney performance. For these and other reasons, the sandbagging argument has been criticized by commentators who otherwise differ greatly on habeas issues. See Friedman, 73 Minn L Rev at 292 (cited in note 19); Friendly, $38 \mathrm{U}$ Chi L Rev at 158-59 (cited in note 4); Guttenberg, 12 Hofstra L Rev at 694-97 (cited in note 23); Meltzer, 99 Harv L Rev at 1197-99 (cited in note 19); Judith Resnik, Tiers, 57 S Cal L Rev 837, 896-98 (1984); and Tague, 31 Stan L Rev at 43-46 (cited in note 19).

${ }^{87}$ See Meltzer, 99 Harv L Rev at 1202-07 (cited in note 19). 
Of course, the states' interests in finality and in enforcing their procedures are well understood. Different observers may weigh them differently, but nobody denies their existence. The real issue is whether these concerns are outweighed by some countervailing interest in allowing habeas review of all outcome-related defaulted claims. In other words, the argument against federal habeas review of defaulted claims that do not go to factual guilt is clear; the question is whether there is any strong argument for hearing such claims.

.We can identify four arguments in favor of federal habeas review of all defaulted claims. First, federal habeas relief might be justified as a deterrent to unconstitutional conduct by state officers. Second, denial of habeas relief might be thought unfair to defendants who are, in moral terms, identical to other defendants whose lawyers raised similar claims in a timely fashion and who consequently obtained relief. Third, federal habeas review might be thought justified by the inherent importance of federal constitutional rights, an argument usually cast as an assertion that there should be no hierarchy among such rights. Fourth, review of nonguilt-related claims might be thought necessary as a surrogate for review of claims that bear directly on guilt or innocence, but that are difficult or impossible to identify. We consider each of these arguments in turn in the sections that follow. ${ }^{58}$

\footnotetext{
${ }^{88}$ All four of the arguments view the process of hearing defaulted claims as valuable for instrumental reasons-because it promotes good outcomes in particular cases, deters official misconduct, or affirms the importance of constitutional rights. One might take a different approach and argue that the process of hearing defaulted claims is valuable not for what it accomplishes, but for its own sake.

Frankly, we consider this position untenable. Process costs money, and it seems sensible to use the limited resources available to our criminal justice system where they will do the most good. For that reason, we start from the premise that process is a means of achieving certain substantive outcomes outside the courtroom-in this context, the proper allocation of criminal punishment and compliance with federal law by state and local officials. Obviously, those who view process as an end rather than a means will find our proposal mistaken.

A variant on this non-instrumental position might be that habeas review is valuable for the satisfaction it gives habeas petitioners, whether or not it achieves any substantive ends. A rich literature (one in which we are far from expert) explores the concept of party satisfaction and its relevance to a society's choices about legal process. See, for example, E. Allan Lind and Tom R. Tyler, The Social Psychology of Procedural Justice 93-106 (Plenum, 1988); John Thibaut and Laurens Walker, Procedural Justice: A Psychological Analysis 67101 (Wiley, 1975). That literature is both important and potentially useful in thinking about how to structure existing systems of dispute resolution. We do not, however, think it useful for deciding whether to litigate a given claim or dispute in the first place. Perhaps habeas petitioners gain some sense of satisfaction from raising Kimmelman-type defaulted claims in federal court. But if litigating such claims accomplishes nothing beyond making petitioners feel good, we have no hesitation in saying it is not worth the costs it imposes on the
} 


\section{Deterrence of unconstitutional conduct.}

The deterrence argument for habeas relief in cases such as Kimmelman is familiar. The police officer who conducted an arguably illegal search presumably wanted to solve a crime and catch a rapist. Undoing the procedural default, vacating the conviction, and suppressing the evidence in a new trial will send a signal to officers in similar positions that illegal searches do not pay. ${ }^{59}$ This argument does not depend on factual innocence; it justifies habeas relief with reasons wholly independent of that concern. ${ }^{60}$

There are, however, good (and familiar) reasons to believe that habeas relief for defaulted claims is, in deterrence terms, insignificant. To be effective, the prospect of deterrence must be visible ex ante. So viewed, the deterrent effect of federal habeas review of defaulted claims is likely to be trivial. The police handle a great many cases. In some cases, constitutional violations would be so obvious and so central as to preclude prosecution altogether. In those cases that go to trial, arguable constitutional violations will almost certainly be raised by defense counsel. The few exceptions, such as Kimmelman, cannot be identified in advance. And any cost to the police in terms of lost convictions will be long delayed. It will come after trial, default, conviction, and affirmance on appeal. Thus, although the matter is incapable of quantification, we are confident that the incremental deterrent effect of federal habeas review of defaulted constitutional claims is vanishingly slight. ${ }^{\text {e1 }}$

federal judiciary, government lawyers, and litigants in other cases who suffer delays because of crowded dockets.

so This is the standard judicial justification for exclusion of evidence. See, for example, United States v Leon, 468 US 897, 906 (1984); Stone v Powell, 428 US 465, 486-88 (1976); and United States v Calandra, 414 US 338, 347-48 (1974). To be sure, some Justices offer different justifications, as noted in James v Illinois, $110 \mathrm{~S} \mathrm{Ct} 648,651$ n 1 (1990), but deterrence is, and has been for some time, the only rationale that commands a Supreme Court majority.

${ }^{30}$ At the outset, one should note an important, though not in itself debilitating, limitation of this argument. Granting habeas relief can, at most, deter constitutional violations by those who are trying to keep convicted defendants in jail. It cannot deter defense counsel, who presumably have a different objective. If anything (we would guess that the effect is small), defense counsel might have a greater incentive to raise claims in timely fashion if they knew that their mistakes were irrevocable. On the other hand, it may be that any such effect would be offset by the stigmatization of a finding of ineffectiveness, which would increase rather than decrease the cost to the lawyer of procedural default. On balance, the deterrent effect on defense counsel is probably not significant one way or the other, and we therefore discount the effect on attorneys as a reason for granting or denying habeas relief.

${ }^{61}$ This conclusion is buttressed by the absence of a comparable deterrence argument in roughly analogous civil contexts. No one claims that a plaintiff who loses a product liability case by failing to object to the introduction of some piece of evidence ought to be permitted to relitigate the case in order to deter unsafe product design. In the civil context, the as- 
Of course, there is another possible target of deterrence. Federal habeas review might be directed not so much against state law enforcement officers as against state judges. ${ }^{62}$ The Supreme Court does not often say much about this point, but one's view of the integrity and reliability of state courts is perhaps the single most important factor in determining the appropriate role for federal habeas corpus.

In defense of our proposed standard, we offer two observations. First, distrust of state courts warrants federal court relitigation of previously considered claims more than it warrants consideration of defaulted claims. In other words, a frank mistrust of state courts would more nearly justify Brown $v$ Allen than Fay $v$ Noia. ${ }^{63}$ And if one were to assume that state courts systematically skew Fourth Amendment decisions in favor of the government, the sensible response would be to overrule Stone v Powell ${ }^{64}$ and institute routine federal habeas review of Fourth Amendment claims heard and rejected in state court. Absent such review, it is hard to

sumption is that neutral procedural rules generate about an even number of mistaken outcomes on each side, and that any bias from such rules is small. To be sure, the civil and criminal contexts differ in important respects, but the differences do not substantially undermine this conclusion. Also, the fact that tort scholarship, which is dominated by incentive and deterrence arguments, has paid no notice to the effects of procedural timing rules on primary conduct suggests that the ultimate effects on deterrence are probably too small to worry about in both contexts.

There may be one class of cases where this point does not hold true. Where government officials conceal evidence of their own misconduct, habeas review, while flawed, may be the only deterrent available. But note that such misconduct will usually implicate innocence concerns: a prosecutor who suppresses evidence of the defendant's innocence gives the defendant a viable claim under any theory of prejudice. As for other claims, such as that the government suppressed evidence of grand jury discrimination, the proper solution may be to require state courts to hear such federal claims in the first instance, rather than to remedy the problem via the law of defaulted claims. In any event, cases of this sort must be a small subset of the cases governed by Sykes and Strickland, and can hardly justify treating all outcome effects alike under those doctrines.

${ }^{62}$ For an extended argument that federal habeas should play precisely this role, see Larry W. Yackle, Explaining Habeas Corpus, 60 NYU L Rev 991 (1985).

es In Brown v Allen, 344 US 443 (1953), the Court determined that federal courts should hear and decide federal constitutional claims that were rejected on the merits in state court. In Fay $v$ Noia, 372 US 391 (1963), the Court held that federal courts should reach the merits of defaulted constitutional claims-i.e., claims that had never been decided on the merits-unless the habeas petitioner deliberately withheld his claim in state court.

It is worth noting that Fay might be a good response to state court intransigence if there were reason to believe that state courts were stretching procedural default rules to bar subsequent federal habeas review of constitutional claims. In our view, the best solution to that problem is to regulate state procedural default rules directly, to ensure that they (1) are not unreasonably harsh, and (2) are applied fairly. For purposes of our argument, we take as a given that the state rules governing procedural defaults meet these standards.

s4 428 US 465 (1976). 
believe that the behavior of state judges would be much influenced by the prospect of federal habeas review of the occasional case where a winning Fourth Amendment claim is defaulted by defense counsel. The exceptional nature of such cases, the difficulty of their identification, and the long delay in obtaining judgments suggest that habeas review of defaulted claims would have little bearing on the general behavior of state judges. We think the system is therefore free to decide defaulted claims with a view toward insuring just outcomes in those cases rather than in pursuit of some more general deterrence of state judges.

More broadly, and perhaps more importantly, we do not believe that any generalized mistrust of state courts is warranted today. Anyone familiar with the Supreme Court's docket twenty or thirty years ago could scarcely have escaped noticing that some state courts, particularly in some areas and particularly with respect to some litigants, were hostile to the enforcement of federal rights. If, as we think, state courts were generally inhospitable to federal rights, habeas review offered the only corrective; direct Supreme Court review of large numbers of federal claims was obviously impossible. Today, however, a review of the Supreme Court's docket confirms that state court enforcement of the Constitution has vastly improved. The Court sees mostly cases that we would describe as borderline-disputes concerning the marginalia of constitutional requirements-rather than, as was once true, cases suggesting wholesale disinterest in constitutional guarantees. There is some evidence to support this view, ${ }^{85}$ but it is ultimately as much a question of evaluation as of observation. In any event, we record our views frankly, not because they are directly relevant to the problem of defaulted claims, but because they form the essential background of our general views on the appropriate role of federal habeas corpus.

\section{Equality among defendants.}

A second possible justification for an outcome-oriented definition of "prejudice" is equality among defendants. Kimmelman, one might say, is not really about the need to deter unconstitutional searches or to ensure that state judges take such claims seriously. Rather, one might argue, Neil Morrison should be granted relief

6s See Craig M. Bradley, Are State Courts Enforcing the Fourth Amendment? A Preliminary Study, 77 Georgetown L J 251 (1988) (concluding, based on a study of appellate opinions in nine states, that state courts do not systematically err in the government's favor in adjudicating Fourth Amendment claims). 
because a similarly situated defendant with a better lawyer would have raised the Fourth Amendment claim, had the bedsheet suppressed, and vitiated the prosecutor's case. Quite plausibly, such a defendant would have been acquitted. There is something wrong, the argument goes, with a system that sends Morrison to jail but lets his hypothetical counterpart rapist go free, where the only difference between the two is the performance of their lawyers. Gary Goodpaster has put the point as follows:

Fairness to the defendant also requires that criminal defendants be treated evenhandedly. Equal protection principles should ensure that the criminal justice system, which relies on defense attorneys of widely varying abilities, skills, knowledge, industry, and professional moralities, does not treat similarly situated defendants unequally. Similar defendants who have committed similar crimes under similar circumstances ought not to receive vastly different dispositions because of their respective lawyers' varying professional attributes. ${ }^{68}$

This intuition has widespread currency, both in the classroom and among thoughtful scholars, but we nevertheless think it wrong. For one thing, the argument proves too much. The inequality complained of is not unique to an innocence-based construction of "prejudice." It exists also under the current regime. Under Sykes a non-ineffective lawyer's error binds the client, placing the defendant in a worse position than a hypothetical defendant who is similarly situated but better represented. Nor could the problem be solved by returning to the Fay rule that claims are defaulted only by the defendant's deliberate bypass, or even by eliminating procedural defaults altogether. So long as some defendants have better lawyers than others, similarly situated defendants will fare differently-unequally, if you will-because of their attorneys.

But this objection strikes only a glancing blow at the equality argument. That across-the-board equality cannot be achieved hardly compels indifference to inequalities that can be corrected. Our greater objection is that the particular inequality in question, while troubling, does not have the moral force commonly ascribed to it. To see why that is so, one need only shift attention from the small-scale inequality among those prosecuted with varying grades of defense counsel to the large-scale inequality between those who are prosecuted for their crimes and those who are not. Many, probably most, criminals are not caught, and many of those who are

6s Goodpaster, 14 NYU Rev L \& Soc Change at 65 (cited in note 20). 
caught are not prosecuted, in some instances because of police oversight or mistake. The inequality between those who are and those who are not caught and tried dwarfs any inequality about which someone in Morrison's position can complain. Yet the much greater arbitrariness resulting from imperfect law enforcement is not commonly thought to raise serious fairness concerns.

Consider the following example. Two confederates rob a bank. One is more slow-footed, less quick-witted, or more easily recognized than the other, and he is caught and convicted. The other gets away. The convicted robber undoubtedly feels aggrieved, but no one, to our knowledge, believes that he has a strong moral claim to equal treatment with his more fortunate confederate. This conclusion does not depend on the supposition that the reasons for the different outcomes were beyond the government's control. The lucky robber might escape only because of police negligence (failure to follow obvious leads, failure to take a suspect into custody at the first opportunity, etc.). Indeed, he might escape punishment only because of unconstitutional police behavior. If the police illegally search his apartment, he would have a Fourth Amendment claim while another robber would not. Again, no one, to our knowledge, suggests that a properly prosecuted defendant should escape punishment simply because the police erred in searching another. The conviction of the one bank robber is not unjust, but merely unlucky. ${ }^{67}$

Neil Morrison is in a position very much like the unlucky bank robber. A factor unrelated to moral blameworthiness (police error or lack of foot speed in the one case, a lawyer's mistake in the other) is a but-for cause of his conviction. A perfectly just system might acquit both Morrison and the bank robber on that ground, for different treatment of like cases is surely a vice. In a system striving to do justice within real-world constraints, however, the bank robber's conviction is always deemed just because the defendant did in fact commit the crime charged. The same should be

67 To be sure, commentators do complain about the broad scope of prosecutorial discretion, but not out of concern for these kinds of formally "unequal" outcomes. The most common concern is that, because of their vast authority, prosecutors may do a good deal of under-the-table lawmaking and may exercise their discretion on illegitimate (and not simply arbitrary) grounds. See, for example, James Vorenberg, Decent Restraint of Prosecutorial Power, 94 Harv L Rev 1521, 1555-57 (1981). Commentators also note that prosecutors may have incentives to not exercise their discretion in a consistently public-interested manner. See Stephen J. Schulhofer, Criminal Justice Discretion as a Regulatory System, 17 J Legal Stud 43, 49-53 (1988). These arguments identify systemic problems associated with prosecutorial discretion, but they do not question the fairness of particular charging decisions to the particular individuals involved. 
true for Morrison. Comparing him to another with a better lawyer may prompt regret about the role of chance in life (and in the administration of criminal justice), but it cannot make a sufficiently strong moral case for exculpation. Were it otherwise, any defendant could escape punishment simply by pointing to others, no less guilty, who avoided criminal liability due to some police or prosecutorial mistake.

A narrower version of the equality argument might seem more promising. Some factors affecting the outcome of trials, even though unrelated to the factual guilt or moral culpability of the defendant, should be excluded because they are invidious. Race is the plainest example, but perhaps not the only one. Pursuing this line of reasoning, one might point out that attorney mistakes likely correlate with client poverty, since poor defendants have court-appointed, and perhaps low-quality, counsel. In this view, the real problem with letting the Kimmelman conviction stand is that it may hurt defendants who are poor ${ }^{68}$ and result in a particular kind of inequality between poor and non-poor defendants. ${ }^{69}$

Here, too, the equality argument cuts too broadly to be convincing. Wealth effects are not limited to, nor are they produced by, trial procedure. A large portion of the prison population are persons who, one might think, would not be there had they been born into middle-class homes. We do not indulge the common but insulting assumption that poor people commit crimes simply because they are poor. But we do think it plausible that many persons who commit crimes would not be the persons they are (and also would not face the temptations they face) had they been born into better economic circumstances. Their claim of invidious treatment on account of wealth seems at least as strong as Morrison's, in the sense that poverty plausibly might be (but in any individual case cannot be proved to be) a but-for cause of punishment.

Most courts and scholars have concluded, however, that punishing such people is not unjust, even if it reminds us of unattractive features of our society, because poverty did not in any real sense compel the commission of crime. ${ }^{70}$ In other words, the persons in question (at least by hypothesis) could have chosen not to

cs This problem may not have occurred in Kimmelman itself, where the defendant retained private counsel.

(o) Perhaps we should say rich and non-rich defendants, for poor defendants are not the only ones who could have a complaint based on wealth inequality. Anyone unable to hire the best could make a similar claim.

${ }^{70}$ See, for example, United States $v$ Alexander, 471 F2d 923, 968 (DC Cir 1973); Sanford H. Kadish, Blame and Punishment 102-03 (MacMillan, 1987); and Stephen J. Morse, 
commit crimes, as do most persons who are similarly situated. Their actions are in a sense "caused" by many factors, some of which have no just bearing on punishment. But so long as the defendant's own choice was one cause of the criminal conduct, conviction is just. $^{71}$

Both for Morrison and for those defendants who might not have committed crimes but for their poverty, the inequality is something to be regretted. At the same time, the poor defendants surely have the stronger claim for relief; they would not have committed crimes at all but for their poverty. Since that claim is not granted by our criminal justice system, it is hard to see why Morrison's should be; his claim is only that he would have been able to escape punishment for his crimes had he been wealthier.

Finally, it is important to note that not all constitutional rights intrinsically require equal treatment of all individuals who may be affected by their administration. Constitutional criminal procedure contains many rules designed to deter governmental misconduct. Implementing these rules benefits some defendants, but that benefit is incidental to the purpose of the rules. It follows that the benefits of such rules need not be made equally available to all, just as the benefits of, say, a punitive damages award in a civil case need not be equally distributed to all victims of the defendant's tortious misconduct. Where a given constitutional requirement is designed to deter police misconduct across the board rather than to secure correct outcomes in individual cases, there is no a priori reason why the protection of that requirement should be equally or comprehensively available to all defendants.

The Twilight of Welfare Criminology: A Reply to Judge Bazelon, 49 S Cal L Rev 1247, 1251-54 (1976).

As the title of Morse's article suggests, the most prominent dissent from these views is David L. Bazelon, The Morality of the Criminal Law, 49 S Cal L Rev 385, 388-98 (1976). For a recent response to Judge Bazelon and to his critics, see Stephen J. Schulhofer, Just Punishment in an Imperfect World, 87 Mich L Rev 1263, 1287-92 (1989) (reviewing David L. Bazelon, Questioning Authority: Justice and Criminal Law (Knopf, 1988), and suggesting that punishment of the sort described in the text is not fair but is nonetheless necessary).

71 The key to this familiar point is to recognize that while many factors, some of them random, may "cause" a criminal action, causation does not logically negate responsible choice. See Michael S. Moore, Causation and the Excuses, 73 Cal L Rev 1091, 1139-48 (1985); Stephen J. Morse, Psychology, Determinism, and Legal Responsibility, in The Nebraska Symposium on Motivation 35, 42-50 (U Nebraska, 1986). The argument is that in many cases both of the following propositions are true: (1) the defendant would not have committed the crime but for his (economically or otherwise) deprived background and circumstances; and (2) most persons from the same background and circumstances would not commit comparable crimes. 
The most important example is the Fourth Amendment exclusionary rule. Justified as a deterrent to unlawful searches, the exclusionary rule results in a windfall for the lucky defendant whose conviction depends on use of the illegally seized evidence. Nothing in the Fourth Amendment, nor in ordinary notions of fairness, requires that this windfall be extended to all who might claim it. That is why the Court has felt free to weigh the marginal cost against the marginal benefit and decide that exclusion shall sometimes be unavailable. ${ }^{72} \mathrm{~A}$ defendant whose house was searched with a warrant but without probable cause may not be able to suppress the evidence-even though the magistrate who issued the warrant got the case wrong. ${ }^{73}$ In contrast, a defendant searched without a warrant would be entitled to suppress the evidence. The difference between the two is purely instrumental. Police officers are in a sense partisans: their job is to catch and help convict criminals. Suppressing evidence when they misbehave thus takes away the benefit they derive from their search. Magistrates, on the other hand, are identified more with adjudication than with law enforcement. Thus, it may make sense to presume that they will try to obey the underlying rules on their own, without the need of any evidentiary club. ${ }^{74}$ The idea is that suppression has only slight benefit in cases where magistrates mistakenly assess probable cause, but is of far greater value where police officers make the same mistake.

Of course, this conclusion may be empirically wrong. It may be that excluding evidence in cases like United States $v$ Leon would be a more useful deterrent than the Court believes. Our point is only that the decision is one that turns, at least under current Fourth Amendment law, wholly on deterrence concerns. Consequently, any resulting "inequality" in the distribution of the benefits of exclusion does not vitiate the rationale for the underlying entitlement.

\footnotetext{
72 See, for example, Walder $v$ United States, 347 US 62 (1954) (allowing use of illegally obtained evidence for purposes of impeachment); United States v Calandra, 414 US 338 (1974) (allowing use of illegally obtained evidence in grand jury proceedings); United States v Janis, 428 US 433 (1976) (allowing use of illegally seized evidence, at least under some circumstances, in civil tax proceedings); United States v Leon, 468 US 897 (1984) (allowing use of illegally seized evidence when the officer relied in good faith on the issuance of a warrant); and INS v Lopez-Mendoza, 468 US 1032 (1984) (allowing use of illegally seized evidence in deportation proceedings). Of course, the Court may have miscalculated in any given case. One need not agree with the specific results to see that the Court has undertaken an inquiry that is entirely consistent with the deterrence rationale for exclusion of evidence.

${ }^{73}$ See Leon, 468 US 897.

${ }^{34}$ See id at 916-17.
} 
The same thing could be said about many other constitutional claims. Confessions obtained in violation of Miranda ${ }^{75}$ or Massiah $^{78}$ may sometimes be unreliable. To that extent, suppression promotes reliable outcomes. But far more commonly, the statements are suppressed in spite of their evidentiary value, as a means of deterring the police from using tactics that might lead to unacceptable abuse. ${ }^{77}$ In this common circumstance, suppression is not intended to generate correct outcomes, but to use the threat of incorrect outcomes to deter police misconduct. It follows that suppression is a necessary evil. When that evil is not necessary, it should not occur. This observation fits well with existing Miranda doctrine. To take the most obvious example, defendants whose $\mathrm{Mi}$ randa rights are violated can suppress incriminating statements made in response to the illegal interrogation, but the same defendants cannot suppress other "fruits" of the police misconduct. ${ }^{78}$ This line does not reflect any difference in the circumstances of the defendants; rather, it reflects deterrence factors that have nothing to do with defendants' just desserts.

Once again, nothing in the nature of constitutional rules of this sort requires that all claimants be equally entitled to their benefits. Nor-at least to our way of thinking-is any overriding notion of equality violated when some but not all defendants are given a windfall benefit for the public good. The Neil Morrisons of the world may or may not partake of that benefit, according to judicial calculation of the public interest, but they should not be heard to complain merely because they are denied a windfall that the exclusionary rule bestows on others.

\section{Affirmation of rights.}

The third possible justification for hearing defaulted claims that have no bearing on guilt is the affirmation, or vindication, of constitutional rights. Affirmation of rights is a symbolic argument (which is not to say that it is an unimportant one), and like many symbolic arguments, its reach is unclear.

In its strongest form, this concern with vindication of rights would imply that every constitutional violation must have a remedy. Of course, any such notion is quickly curtailed by the doctrine

76 Miranda v Arizona, 384 US 436 (1966).

${ }^{76}$ Massiah v United States, 377 US 201 (1964).

37 For general discussion of this point in the context of Miranda rights, see William J. Stuntz, Waiving Rights in Criminal Procedure, 75 Va L Rev 761, 807-22 (1989).

${ }^{78}$ See Oregon v Elstad, 470 US 298 (1985). 
of harmless error. ${ }^{79}$ Many, probably most, constitutional violations go unremedied because they are harmless. They are harmless, that is, in that they do not affect outcomes. Viewed from a symbolic concern for the affirmation of rights, constitutional violations that do not affect outcomes might not be harmless at all. Though superficially plausible, this view is widely rejected because it would demand a perfection in the administration of justice that no human institution can achieve. Therefore, affirmation of rights is usually said to require the remedying of all non-harmless errors, although it is hard to see why that is anything more than an arbitrary stop in the reasoning.

More commonly, the concern for affirmation of rights takes the form of the negative claim that there should be no hierarchy among constitutional rights. This is an important assertion, for it poses the chief rhetorical barrier to differentiating among claims according to their impact on innocence. Rebuttal is essential to our case, and requires separate consideration of two allied strands of the argument: first, that the Constitution itself admits of no hierarchy of rights; and second, that in any event the habeas corpus statute does not permit differentiation among the rights to be enforced.

The assertion that the Constitution admits of no ranking of rights or values is commonly made, ${ }^{80}$ but deeply puzzling. In a sense, all of modern constitutional law is to the contrary. The famous footnote four of Carolene Products is celebrated precisely because it laid the foundation for a redirection of emphasis among constitutional rights. ${ }^{81}$ Modern theorists do battle over the criteria

79 The Supreme Court has emphasized that, with rare exceptions, errors that clearly did not affect the outcome of a criminal proceeding cannot justify reversal. See, for example, Rose $v$ Clark, 478 US 570, 579 (1986) ("The thrust of the many constitutional rules governing the conduct of criminal trials is to ensure that those trials lead to fair and correct judgments. Where a reviewing court can find that the record developed at trial establishes guilt beyond a reasonable doubt, the interest in fairness has been satisfied and the judgment should be affirmed.").

For a recent, comprehensive effort to unravel the Court's harmless-error jurisprudence (and also to suggest some changes), see Tom Stacy and Kim Dayton, Rethinking Harmless Constitutional Error, 88 Colum L Rev 79 (1988).

80 See, for example, Friedman, 73 Minn L Rev at 320 (cited in note 19) ("ranking of constitutional rights finds no basis in the habeas statute or the Constitution itself'); and Stacy and Dayton, 88 Colum L Rev at 90 (cited in note 79) ("The Constitution does not create a hierarchy of rights or values.").

81 United States v Carolene Products Co., 304 US 144, 152 n 4 (1938). There is a massive literature on Carolene Product's transformation of constitutional law. For some deservedly famous discussions, see John Hart Ely, Democracy and Distrust (Harvard, 1980); Bruce A. Ackerman, Beyond Carolene Products, 98 Harv L Rev 713 (1985). 
for constitutional adjudication, but all envision something other than a featureless plane of undifferentiated rights. No one thinks the Second Amendment is as important as the First, or that the cumulation of precedent leaves the Tenth and Fourteenth Amendments effectively unranked. The "economic" and "personal" aspects of constitutionally protected "liberty" have been sharply distinguished; ${ }^{82}$ the apparent exclusivity of Article III adjudication is more hole than cheese; ${ }^{83}$ and the Commerce Clause has expanded beyond recognition. ${ }^{84}$ Whatever may be said for or against these decisions, they all proceed from the common ground that there is a hierarchy among constitutional protections. The only sense in which this is not true is the verbal sleight of hand that some rights have been greatly expanded, while others have been defined away, but that all rights, as reconstructed, have a sort of nominal equality. This fiction is too threadbare to require rebuttal.

The real point of the no-hierarchy-of-rights rhetoric, we believe, is not that differentiation among constitutional rights is inherently wrong, but that it is impermissible to introduce such differentiation into the law of habeas corpus. The contention is that rights that are vindicated on direct appeal must also prevail on collateral review. Properly understood, this argument is not about the nature of constitutional rights but about the scope of federal habeas corpus.

Both commentators and Supreme Court justices have observed that the federal habeas statute gives no textual warrant for differentiating among constitutional rights. ${ }^{85}$ That is true. It is also true that virtually all ingredients of federal habeas law were announced without statutory authority. At least since 1886, federal habeas law has developed by judicial innovation, followed (sometimes) by legislative ratification. This is true of the exhaustion re-

${ }^{82}$ Compare, for example, the deference paid to state rules that affect individuals' interest in choosing their occupations, see Williamson v Lee Optical Co., 348 US 483 (1955), with the exacting scrutiny paid to state regulation of personal associations, Moore $v$ City of East Cleveland, 431 US 494 (1977).

${ }^{8 s}$ Northern Pipeline Co. $v$ Marathon Pipe Line Co., 458 US 50 (1982), may represent the last bit of cheese.

34 For two examples of the limitless reach of the Clause, see Garcia $v$ San Antonio Metropolitan Transit Authority, 469 US 528 (1985); and Wickard v Filburn, 317 US 111 (1942).

${ }^{83}$ See Stone v Powell, 428 US at 503-06, 515-33 (Brennan dissenting); J. Patrick Green, Stone v. Powell: The Hermeneutics of the Burger Court, 10 Creighton L Rev 655 (1977); and Mark Tushnet, Constitutional and Statutory Analyses in the Law of Federal Jurisdiction, 25 UCLA L Rev 1301, 1316-18 (1978). 
quirement, which was announced in $1886,{ }^{88}$ codified in $1948,{ }^{87}$ and has been significantly modified since then. ${ }^{88}$ It is also true of the range of legal issues that, once heard in state court, could be relitigated on federal habeas corpus. Decisions early in this century defined a relatively narrow scope for relitigation (whether in accord with congressional intent, we do not say). ${ }^{89}$ The range of such claims cognizable on federal habeas review was expanded in Brown $v$ Allen $^{90}$ and partly contracted in Stone $v$ Powell, ${ }^{91}$ all without aid of statutory intervention. Similarly, the scope of relitigation of the facts underlying federal claims was first announced by decision ${ }^{92}$ and only later codified by statute..$^{93}$

Finally, and most to the point, judicial innovation has determined the scope of habeas review for defaulted claims. Whatever one might say about the supposed original intent of the habeas statute, ${ }^{94}$ federal habeas review of defaulted claims was at first

${ }^{8 e}$ Ex parte Royall, 117 US 241 (1886).

${ }^{87}$ Act of June 25, 1948, ch 646, 62 Stat 967 (1948), codified at 28 USC $\S 2254(b),(c)$ (1982).

See Rose $v$ Lundy, 455 US 509 (1982).

sa This historical issue has occasioned a good deal of debate. The standard argument that Congress intended the 1867 habeas statute to cover only jurisdictional claims is made in Bator, 76 Harv $L$ Rev at 463-77 (cited in note 53). For the argument that the statute was meant to cover a much larger category of claims, see Gary Peller, In Defense of Federal Habeas Corpus Relitigation, 16 Harv CR-CL L Rev 579, 603-63 (1982).

${ }^{80} 344$ US 443 (1953). Brown extended the scope of federal habeas to federal constitutional claims generally, holding that it did not apply merely to claims bearing on the jurisdiction or authority of the relevant state court.

${ }^{22} 428$ US 465 . Stone barred relitigation of Fourth Amendment claims, save where the defendant did not receive a full and fair opportunity to litigate the claim in state court.

${ }_{92}$ Townsend $v$ Sain, 372 US 293 (1963).

93 Act of Nóv 2, 1966, Pub L No 89-711, § 2, 80 Stat 1105 (1966), codified at 28 USC § 2254 (d) (1982). Section 2254 requires a federal habeas court to defer to "a determination after a hearing on the merits of a factual issue, made by a State court." Interestingly, the statutory amendment departed from the Court's pronouncements in a way that, although seemingly significant, was not given effect until the Court itself decided to constrict the scope of factual relitigation. Sumner v Mata, 449 US 539 (1981), on review following remand, 455 US 591 (1982) (per curiam), held that § 2254(d) applies when a state appellate court made the factual findings, as well as when a trial court made the factual findings. In Mata, the majority's ahistorical emphasis on statutory text had a constrictive rather than expansive effect on the scope of the federal habeas remedy, perhaps explaining why the approach has not received approval from all quarters. Compare Mata, 449 US at 544-49 (majority opinion undertaking a close text-bound construction of $\S 2254$ (d)) with id at 55559 (Brennan dissenting) (emphasizing prior Supreme Court decisions rather than the statutory text).

at Compare Fay v Noia, 372 US 391, 399-415 (1963) (arguing from history for broadly available habeas relief for defaulted claims) with id at 449-63 (Harlan dissenting) (arguing from history for the opposite conclusion). 
completely foreclosed, ${ }^{96}$ then substantially allowed, ${ }^{96}$ and later partly restricted, ${ }^{97}$ all without statutory change. Indeed, the issue is not now, and never has been, expressly resolved by statute.

Against this background, one can hardly insist on the primacy of legislative innovation in the law of federal habeas corpus. To put the matter bluntly, it is simply too late in the day to assert a lack of judicial authority to reform habeas law. ${ }^{98}$ No doubt the separation of powers argument, as it is sometimes called, is attractive to one who is alarmed at the direction of judicial innovation, but this kind of tactical response will not do. Judicial authority to expand habeas review necessarily implies the authority to restrict it also. That, at least, is the view taken by the Supreme Court, ${ }^{99}$ and we think it fairly meets the expectations in this field. At the very least, it applies where, as here, prior decisions have not been codified.

This is not to say that Congress could not override the Court's decisions, nor that a genuine legislative command ought not be respected. It is only to acknowledge that the pattern of statutory amendment in this area has been merely to confirm judicially announced changes in the law. We suggest that this tradition should be presumed to continue, unless and until Congress indicates its dissatisfaction.

In short, there is nothing inherently wrong with differentiating among constitutional rights, either directly or as a condition of habeas review. The question is not whether such distinctions are in principle permissible - surely they are-but whether they are wise. In our view, it is wise to differentiate among constitutional claims according to whether they raise a "reasonable possibility" of factually erroneous conviction (or factually unsupported sentence of death), at least when these claims were defaulted in state court. This approach would, in most cases, respect the states' interests in finality of judgments and in enforcing legitimate procedural requirements. At the same time, it would vindicate the overriding

9s Brown v Allen, 344 US 443 (1953).

- Fay, 372 US 391.

97 Sykes, 433 US 72; Carrier, 477 US 478.

"B David Shapiro has argued that this proposition extends well beyond federal habeas: that the exercise of judicial discretion is a proper and useful part of defining the bounds of federal jurisdiction as a general matter. See David L. Shapiro, Jurisdiction and Discretion, 60 NYU L Rev 543 (1985).

ov See Sykes, 433 US at 81 (analysis of Court's habeas decisions "illustrates this Court's historic willingness to overturn or modify its earlier views of the scope of the writ, even where the statutory language authorizing judicial action has remained unchanged."). 
federal interest in hearing federal claims suggesting unjust conviction or punishment. The federal interest would be addressed directly, without the deflective intermediate step of categorizing reasons for the default. Defaulted federal claims that do not arguably demonstrate innocence (or unjustified sentence of death) would not be heard on habeas corpus, simply because there is no compelling reason to do so.

\section{Attorney ineffectiveness and pervasive neglect.}

Paradoxically, review of non-guilt-related defaulted claims might be thought necessary to protect innocence. One could argue that a defense attorney's incompetent handling of an issue signals possible incompetence in other areas-including matters not known to the court or, for that matter, to the defendant. This point suggests that even if the law were concerned solely with preventing unjust convictions, attorney ineffectiveness could be a useful tool for determining which convictions are unjust. Indeed, the Strickland Court suggested as much, in the course of explaining why it was not adopting an even more stringent prejudice standard than reasonable probability. ${ }^{100}$

The idea of attorney error as a sign of pervasive neglect implies that claims of the sort raised in Kimmelman must be heard not because those claims themselves suggest injustice, but because the underlying attorney errors do. One might say that in Kimmelman, for example, the defense attorney's failure to move to suppress the bedsheet calls into question the competence of the rest of his representation. Perhaps, the argument goes, Neil Morrison was not really guilty, but was convicted only because an attorney foolish enough not to file a suppression motion was also sufficiently inept to botch an available factual defense. ${ }^{101}$

This point has some rough plausibility. It is a familiar idea that one instance of misconduct may be evidence of other undiscovered misconduct, and this proposition surely holds true of professional incompetence. Nevertheless, it would be a mistake to weigh this chain of inferences too heavily. The fact that errors

\footnotetext{
${ }^{100}$ See Strickland, 466 US at 694 (rejecting the more-probable-than-not outcome determinative standard used for newly-discovered evidence claims, and noting that "[a]n ineffective assistance claim asserts the absence of one of the crucial assurances that the result of the proceeding is reliable, so finality concerns are somewhat weaker and the appropriate standard of prejudice should be somewhat lower").

${ }^{101}$ See Strickland, 466 US at 710 (Marshall dissenting); and Berger, 86 Colum L Rev at 92-93 (cited in note 20). This, of course, is the accuracy-based argument for the performance prong.
} 
sometimes come in bunches does not change the fact that they often come alone. More importantly, the signaling argument requires simultaneous acceptance of three propositions: that the error in question indicates a substantial likelihood of other errors; that those other errors bear on the defendant's guilt or innocence; and that those other errors are undiscoverable. For if errors that suggest injustice are uncovered, they can support a claim directly, making it unnecessary to use non-guilt-related errors as a marker for pervasive incompetence. We think it likely that Kimmelmantype mistakes coexist only rarely with other, undiscoverable errors that result in the conviction of innocent defendants.

This conclusion is reinforced by another aspect of ineffective assistance doctrine. In United States $v$ Cronic, the Court held that truly pervasive neglect by counsel (or action by the government that pervasively prevented counsel from doing his or her job) requires reversal without any showing of prejudice. ${ }^{102}$ Although the Court discussed pervasive neglect in the context of a claim that defense counsel lacked adequate time to prepare the case, there is no reason why Cronic should be limited to that context. When a defense attorney makes a series of mistakes rather than an isolated error, the inference of pervasive neglect is much stronger. Accordingly, when a defense attorney has made a series of clear misjudgments, the case should be treated as one where the possibility of injustice is high regardless of the nature of the attorney's mistakes. This would require some expansion of Cronic's scope, but the expansion seems wholly appropriate. ${ }^{103}$ In short, Cronic implements the signaling insight by allowing for relief when there is reason to believe that counsel did many things badly. Given the Cronic remedy, it seems excessive to assume pervasive neglect based only on evidence of one discrete attorney mistake, even if the error was serious.

${ }^{102} 466$ US 648, 657-62 (1984) (prejudice may be presumed when there has been "a breakdown in the adversarial process that would justify a presumption that [the defendant's] conviction was insufficiently reliable to satisfy the Constitution").

${ }^{103}$ Lower courts have generally assumed that Cronic applies to pervasive defense attorney neglect, and not simply to excessive constraints placed on defense counsel by the government. See LaFave and Israel, 2 Criminal Procedure $\$ 11.10$ (a) at $39 \mathrm{n} 22.8, \S 11.10$ (d) at $51 \mathrm{n} 76.10$ (Supp 1989) (cited in note 39). At the same time, the lower courts have defined pervasive neglect very narrowly. Id. If the courts reduced the number of Strickland claims by defining prejudice in guilt-related terms, they could expand the scope of Cronic by defining pervasive neglect to include all cases with a large number of serious attorney errors. 


\section{Defining and Applying a Guilt-Related Prejudice STANDARD}

We have suggested that the law of defaulted claims should be radically simplified by limiting relief to cases where the defendant can show that the default created a reasonable possibility of an unjust result. What that standard would mean in practice depends on how it is applied. In particular, any rule for defaulted claims must take account of the different categories of constitutional rules at issue in federal habeas. Some constitutional claims are wholly unrelated to guilt. Others clearly bear on the accuracy of the defendant's conviction. A third category of claims invoke constitutional rules that enhance the accuracy of criminal adjudications generally, but have an indeterminate effect on any particular case. Finally, an increasing number of federal habeas petitions challenge death sentences rather than criminal convictions. These different types of constitutional claims raise different issues of habeas administration, and complicate the definition and application of any rule for defaulted claims. What follows is an attempt to deal with these differences in a way that is consistent with a focus on preventing unjust outcomes, but that avoids the complexity of the Court's defaulted claims jurisprudence.

To explain how our proposed standard might work in practice, we apply it to four of the Court's recent procedural default decisions, representing the four kinds of federal constitutional claims mentioned in the preceding paragraph. Kimmelman $v$ Morrison involved a Fourth Amendment claim unrelated to the defendant's guilt. The defendant in Murray $v$ Carrier raised a due process claim that went directly to the accuracy of his conviction. Teague $v$ Lane offers an example of a systemic accuracy-enhancing rule that may or may not have affected the outcome in that particular case. Finally, Dugger $v$ Adams involved an Eighth Amendment challenge to the defendant's death sentence.

\section{A. Non-Guilt-Related Claims: Kimmelman v Morrison ${ }^{\mathbf{1 0 4}}$}

Kimmelman, for us, is an easy case. The defendant had a plausible claim that the bedsheet introduced in his rape trial had been illegally seized. Defense counsel did not object to the evidence in a timely fashion. The evidence was therefore admitted, and the defendant was convicted. The Supreme Court found that 
the lawyer's error could show ineffective assistance of counsel, which would support federal habeas review of the defaulted Fourth Amendment claim.

Under our approach, the defaulted claim would not be reopened. Whatever the character of the lawyer's error, there is no chance that the failure to ask for suppression impaired the accuracy of the conviction. On the contrary, the admission of relevant, non-misleading physical evidence could only have enhanced the accuracy of the outcome, however unwelcome that effect may have been to a guilty defendant. We therefore would have denied habeas review, unless it could have been shown that the lawyer's error was not an isolated default, but rather part of a larger pattern of incompetence that undermined the reliability of the defendant's conviction.

It is perhaps conceivable that an isolated error could be so extravagant as to call into question the lawyer's ability to do anything else correctly, but we think that kind of loose inference should prevail, if at all, only in extraordinary cases. Generally speaking, pervasive incompetence should require proof of more than an isolated mistake-particularly where, as in Kimmelman, counsel's error seems to have actually increased the reliability of the guilt determination.

The same result would follow in virtually every case of a defaulted Fourth Amendment claim. We think that entirely proper. We also note that our approach has the advantage (others will view it differently) of aligning the Sykes standard for review of defaulted claims with the Stone $v$ Powell limitation of habeas review of litigated claims. It is an indictment of current law that these two channels for federal habeas review of Fourth Amendment claims are unaccountably divergent. We see no reason for the disparity and would extend the policy of Stone $v$ Powell to defaulted as well as litigated claims, so long as there was a full and fair opportunity to raise the claim in state court.

\section{B. Guilt-Related Claims: Murray v Carrier ${ }^{105}$}

Prior to Carrier's trial for rape and abduction, his lawyer sought to discover the victim's statements to the police. The trial judge examined the statements in camera, concluded that none was exculpatory, and denied discovery. This was almost surely error, since, as Justice Stevens pointed out in his concurrence, "the 
conclusion that there was no 'exculpatory' material in the victim's statements does not foreclose the possibility that inconsistencies between the statements and the direct testimony would have enabled an effective cross-examination to demonstrate that [Carrier] is actually innocent." ${ }^{106}$ In an apparent oversight, Carrier's lawyer failed to include the discovery claim in his petition for appeal, thereby defaulting the claim under state law. The Supreme Court concluded that (1) the Sykes cause-and-prejudice test applies to procedural defaults on appeal as well as at trial, ${ }^{107}$ and (2) nonineffective lawyer error was not "cause" for a procedural default. ${ }^{108}$ (The Court also said that ineffective assistance would constitute "cause," but that this claim should be exhausted in state court before federal habeas review.) ${ }^{109}$ Since Carrier did not claim that the lawyer's oversight amounted to ineffective assistance of counsel, the default was conclusive.

Our approach to this case would be more direct. We would ask only if there was a "reasonable possibility" that the failure to make the victim's statements available to defense counsel resulted in the conviction of one who was factually innocent. Answering that question would require an analysis of the statements Carrier sought to discover, together with the victim's testimony at Carrier's trial, to determine whether the course of the trial plausibly could have been different had defense counsel known the contents of the statements. We have not examined the record, and cannot say what conclusion that analysis would yield. But we are confident that it focuses on the right question.

This approach should not be especially burdensome for federal habeas courts. Indeed, courts should find our analysis natural, since it is precisely the analysis that governs the merits of Carrier's claim. Carrier's claim is that the government failed to disclose material exculpatory evidence. Under a line of cases governing prosecutors' duty to disclose exculpatory evidence, a defendant is entitled to have his conviction overturned if the nondisclosure of such evidence created a reasonable probability of an effect on the outcome. ${ }^{110}$ Satisfying this standard would necessarily satisfy our proposed prejudice standard. Thus, under our approach, Carrier's

\footnotetext{
${ }^{108}$ Id at 499 (Stevens concurring).

${ }_{107}$ Id at $490-92$ (majority opinion).

108 Id at $485-88$.

102 Id at 488-89.

${ }^{110}$ See United States v Bagley, 473 US 667 (1985); United States v Agurs, 427 US 97 (1976); and Brady $\cup$ Maryland, 373 US 83 (1963).
} 
claim should be granted if it is a valid claim on the merits, and not otherwise. The presence or absence of "cause"-the issue that dominated forty-five pages in the United States Reports-would. be irrelevant.

Our approach is similar to, but a good deal simpler than, that offered by Justice Stevens in his separate opinion in Carrier. ${ }^{111}$ Stevens argued that the focus should be on "prejudice" rather than on "cause" whenever the claim relates to fundamental fairness, a category that, for Stevens, would extend beyond guilt-relatedness. ${ }^{112}$ Otherwise, apparently, the ordinary cause and prejudice test would apply. Additionally, in cases where the claim does relate to fundamental fairness, Stevens apparently would require a federal habeas court to balance the interests protected by the claim against the state's interest in enforcing the relevant procedural rule. ${ }^{113}$ It is not clear how courts are supposed to balance such incommensurate interests in specific cases, and we think the inquiry is in any event unnecessary. It would be sufficient-and a good deal easier-to ask directly whether Carrier had shown a "reasonable possibility" of a factually unreliable conviction and there let the matter rest.

C. Claims Involving Systemic Accuracy-Enhancing Rules: Teague $v$ Lane $^{114}$

Teague, a black man, was convicted of attempted murder, armed robbery, and aggravated battery by an all-white jury. The prosecutor had obtained the all-white jury by using all ten of his peremptory challenges against blacks. Teague's lawyer objected on the ground that this process violated the Sixth Amendment requirement that the jury represent a fair cross-section of the community; this objection was overruled. On federal habeas corpus, Teague pressed three related claims: (1) that the prosecutor violated Batson $v$ Kentucky, ${ }^{115}$ which announced, after Teague's trial, that the Equal Protection Clause prohibited (at least in some circumstances) the race-based use of peremptory challenges; (2) that the prosecutor also violated the more lax pre-Batson equal protec-

11477 US at 497-516 (Stevens concurring).

112 See Rose v Lundy, 455 US 509, 543-44 (1982) (Stevens dissenting).

113 See Carrier, 477 US at 506 (Stevens concurring) ("An inquiry into the requirements of justice requires a consideration, not only of the nature and strength of the constitutional claim, but also of the nature and strength of the state procedural rule that has not been observed.").

114109 S Ct 1060 (1989).

115476 US 79 (1986). 
tion standard of Swain $v$ Alabama; ${ }^{116}$ and (3) that the prosecutor violated the Sixth Amendment's fair cross-section requirement.

The Court's resolution of these claims illustrates the excessive proceduralization of habeas review. Each theory was rejected for a different reason, none of which addressed the merits of the relevant claim. First, the Batson argument was rejected on the ground that, as the Court had held previously, ${ }^{117}$ Batson did not apply to convictions that had become final before the decision was announced. Second, the Swain claim was rejected because it had been defaulted: Teague's lawyer had not raised the equal protection argument at trial or on direct appeal. Finally, and most importantly, the fair cross-section claim was rejected because it required a departure from existing Sixth Amendment doctrine. A plurality of the Court declared that new rules of that sort ${ }^{118}$ could not be applied retroactively on federal habeas corpus. The plurality concluded that the new rule sought by Teague could be approved only if other litigants in his position would also enjoy its benefit. Since a new Sixth Amendment requirement governing peremptory challenges would not apply retroactively on federal habeas corpus (as in Batson), neither could it be announced on federal habeas corpus. ${ }^{119}$ In other words, the Court concluded that even if Teague's Sixth Amendment claim was valid, he could not get the benefit of it on federal habeas corpus. The Court thus denied all three related claims without reaching the merits of any of them.

Teague provides wonderful fodder for law school exam questions, but it only complicates the administration of habeas corpus. The retroactivity tangle that dominated the opinion and the proce-

116380 US 202 (1965). Under Swain, defendants had to prove, in essence, a pattern of race-based peremptory challenges unrelated to the nature of the case or the defendant. See id at 223-24 (describing the kind of evidence that would give rise to an inference of purposeful discrimination). A defendant could not make out an equal protection claim based solely on the prosecutor's decision to strike members of the defendant's race in the defendant's case.

${ }^{117}$ See Allen v Hardy, 478 US 255 (1986) (per curiam).

118 A different result might have been reached had the new rule concerned a procedure "without which the likelihood of an accurate conviction is seriously diminished." $109 \mathrm{~S} \mathrm{Ct}$ at 1076-77.

119 The retroactivity analysis was announced in a plurality opinion by Justice O'Connor, joined on this point by the Chief Justice and Justices Scalia and Kennedy. Justice White did not join this portion of Justice O'Connor's opinion, although his separate opinion does not disagree with the plurality's analysis or result. See id at 1078-79 (White concurring in part and concurring in the judgment). In any event, a majority of the Court later adopted Teague's retroactivity analysis and applied it to rules governing the imposition of capital punishment. See Penry v Lynaugh, 109 S Ct 2934, 2944-47 (1989). 
dural bar doctrine that precluded the Swain claim share a common objective. Both are designed to allow relief in cases of injustice, but otherwise to avoid wholesale collateral review of federal claims. ${ }^{120}$ Teague illustrates the complexities of an essentially procedural approach to this objective. Yet the issue is not so difficult if approached directly.

We would ask simply whether the prosecutor's conduct in striking blacks from the jury raised a "reasonable possibility" of a factually unreliable conviction. Quite possibly, such a showing could be made. The race-based use of peremptory challenges would tend to undermine the accuracy of determinations of guilt, at least in close cases. Thus, in a general way, the Batson rule is designed to secure just outcomes, not merely to deter misconduct that is otherwise objectionable. ${ }^{121}$ The force of this point is amplified when one remembers that the accuracy of conviction concerns not merely the fact, but also the grade, of criminal liability. Even if it were clear beyond doubt that Teague was guilty of some form of assaultive behavior, the jury may have had room for judgment as to the appropriate grade of criminal liability. ${ }^{122}$ Accordingly, we think it likely that Teague could have shown a "reasonable possibility" of factual error, and, in any event, that this is the right battleground. If such error could be shown, it is simply intolerable not to grant relief.

Having said that, we add that cases like Teague raise difficult administrative issues: they involve protections that promote accuracy in a systemic sense, yet do not necessarily affect accuracy in any particular case. In other words, the fact that the Batson rule was designed in part to promote accuracy does not mean that every violation of that rule creates a significant risk of an inaccurate judgment. The task is to find a mechanism for separating those cases in which the jury selection might have led to an unjust conviction from those cases in which any jury would have convicted. That is precisely what the Court's approach, focusing on

120 On the role of retroactivity in protecting against basic injustice, see Penry, $109 \mathrm{~S} \mathrm{Ct}$ at 2952-53; and Teague, $109 \mathrm{~S} \mathrm{Ct}$ at 1076-77. On the role of habeas review of defaulted claims in serving the same goal, see Sykes, 433 US at 90-91.

${ }^{121}$ See Allen $v$ Hardy, 478 US 255, 259 (1986) (accuracy of results is one justification for the Batson rule).

122 Teague was found guilty of three counts of attempted murder, two counts of armed robbery, and one count of aggravated battery. The court entered judgment only on the attempted murder and armed robbery counts, sentencing him to thirty years' imprisonment on each count. People v Teague, 108 Ill App 3d 891, 439 NE2d 1066, 1068 (1982).

Teague's lawyer sought an instruction for lesser included offenses at trial, but the trial court refused. That decision was upheld on appeal. $439 \mathrm{NE2d}$ at 1076-77. 
retroactivity, does not do. Retroactivity analysis inevitably has an all-or-nothing character; either everyone with Teague's claim will receive a new trial or no one will. Since the number of cases at stake is large, and the number of potential injustices a good deal smaller, the Court predictably has decided that the costs of blanket reversal are too high. Those costs are a good deal more bearable, however, if one aims to distinguish worthy from unworthy claimants.

The only solution is to look at the record to see whether the case was close on the merits. If the evidence against Teague was overwhelming, he should not get relief. On the other hand, if a reasonable jury could have acquitted (and if no inadmissible evidence clearly established guilt), he should get relief, for the very sort of bias that Batson aimed to prevent might have caused an unjust conviction. In other words, a viable Batson claim should entitle Teague to greater-than-usual scrutiny of the sufficiency of the evidence against him, but not to automatic reversal.

This approach makes it unnecessary to consider either Teague's Swain claim or his fair cross-section claim. Teague could thus obtain the benefit of his most clearly meritorious legal theory (and courts could avoid his more controversial claims), because the prejudice standard sufficiently limits the universe of possible claims.

Our approach also makes the retroactivity analysis that lay at the heart of Teague unnecessary. This is no small benefit. The most recent term of the Supreme Court suggests that retroactivity is likely to become the newest, and perhaps the messiest, procedural thicket to trip up habeas courts. Deciding retroactivity under the Court's analysis requires a federal court to determine both (1) whether the defendant's claim requires adoption of a "new rule" or merely application of existing law, ${ }^{123}$ and if the former, (2) whether the new rule is one "without which the likelihood of an accurate conviction is seriously diminished."124 Each of these issues is complicated and hard. Many arguments involve some marginal alterations of existing law, and no one knows when such arguments seek "new rules" and when they do not. And many constitutional rules protect innocent defendants sometimes, yet do not necessarily protect innocence in any particular case. An approach that looks directly to the merits avoids both of these categorization problems. And although retroactivity analysis extends beyond defaulted

\footnotetext{
${ }^{128}$ See Butler v McKellar, 110 S Ct 1212, 1216-18 (1990).

124 Teague, $109 \mathrm{~S} \mathrm{Ct}$ at 1076-77; see also Saffle v Parks, $110 \mathrm{~S}$ Ct 1257, 1268-64 (1990).
} 
claims, we suspect that a substantial portion of the cases that raise retroactivity issues will, like Teague itself, involve efforts by counsel to excuse a procedural default by pointing to new law. Making such claims easier to decide would go far toward untying the procedural knot Teague has created. ${ }^{125}$

\section{Challenges to Death Sentences: Dugger $v$ Adams ${ }^{126}$}

Adams was convicted of murdering an eight-year-old girl in 1978. At his capital sentencing proceeding, the trial judge repeatedly told the jury that its recommendation would be advisory only and that the court had ultimate responsibility for fixing the sentence. These instructions were improper under state law because the jury's recommendation enjoyed a presumption of correctness and could be overturned only on clear and convincing evidence of error, but the defense counsel did not object. The jury recommended death, and the court imposed this sentence.

On federal habeas corpus, Adams argued that the judge's instruction violated Caldwell v Mississippi, ${ }^{127}$ a 1985 decision holding that the Eighth Amendment requires that juries not be misled about their role (as set by state law) in imposing death sentences. Adams won in the lower courts, but the Supreme Court reversed. The Court found that, even though Caldwell had not been decided at the time of Adams's sentencing, his claim was barred by his law-

\footnotetext{
${ }^{125}$ Eliminating retroactivity analysis is useful generally, but particularly so in cases (unlike Teague) where the prejudice issue is easy. For example, in Butler v McKellar, $110 \mathrm{~S}$ Ct 1212 (1990), the defendant declined to talk to the police and asked to see a lawyer when police questioned him about an assault charge. The next day, officers gave him Miranda warnings, and, with the defendant's permission, proceeded to question him about a thenunsolved murder. He made several incriminating statements, all of which were concededly voluntary and reliable. $110 \mathrm{~S} \mathrm{Ct}$ at 1214-15. The defendant argued, correctly, that these statements were obtained in violation of the Supreme Court's decision in Arizona v Roberson, 486 US 675 (1988), which held that police may not question a defendant who has invoked his right to counsel, even if the questioning concerns a different crime. Roberson was decided long after Butler's conviction became final. In a detailed and controversial application of Teague, the Court found that Roberson had created a "new rule," and was not merely an application of existing law. $110 \mathrm{~S} \mathrm{Ct}$ at 1216-18. Consequently, the Court held, Roberson could not be applied retroactively to Butler's case.

Butler's claim was not defaulted. Had it been, the Court's analysis would have been even more complicated: the Court would have had to consider whether Roberson created the type of new rule that satisfies Sykes "cause." See notes 14-16 and accompanying text.

There is a much simpler way to resolve cases of this sort. Butler's claim resembles the claim in Kimmelman $v$ Morrison, since it aims to suppress concededly reliable evidence of guilt. Thus, the claim cannot possibly raise any serious doubt about the fairness of Butler's conviction. At least if the claim were defaulted, we would deny relief on that ground alone.

136 109 S Ct 1211 (1989).

127472 US 320 (1985).
} 
yer's failure to object to the instruction. The reasoning behind this conclusion is a little complex. A Caldwell Eighth Amendment claim logically requires a violation of state law. If the instructions accurately state the role assigned to the jury by state law in capital sentencing proceedings, there is no Eighth Amendment violation. Even though Caldwell was decided later, the Court concluded that the underlying error of state law should have been recognized at the time of Adams's sentencing. Therefore, the Court concluded, the lawyer's failure to raise the state law claim barred federal habeas review of the associated Eighth Amendment claim.

In one sense, Adams's claim closely resembles Teague's. Both involve systemic rules that enhance the accuracy of jury decisionmaking. The two cases are different, however, because of the difference between capital sentencing proceedings and more ordinary criminal adjudications. Given the judgmental and evaluative character of the criteria used to sentence Adams to death, ${ }^{128}$ we think it very likely that Adams could have shown a "reasonable possibility" of error, though that ultimately would depend on the evidence.

The point can be generalized. Our approach is broadly forgiving of procedural defaults concerning the sentencing stage of capital proceedings. The reason is not primarily that the death penalty is special, although that may be thought sufficient. The reason is that the statutory and constitutional criteria governing the death sentence involve irreducible elements of subjectivity and discretion. ${ }^{129}$ Where that is so, the concept of factual reliability loses its

${ }^{128}$ The trial judge, in upholding the jury's recommendation of death, found three aggravating and three mitigating circumstances. The aggravating circumstances were (1) that the murder was committed in the course of a rape and/or kidnapping, (2) that it was committed for the purpose of preventing arrest, and (3) that it was "especially heinous, atrocious, or cruel." Adams v State, 412 S2d 850, 854 (Fla 1982). The mitigating factors were (1) that Adams had no significant prior criminal history, (2) that he was "under the influence of extreme mental or emotional disturbance," and (3) that he was only 20 years of age at the time of the crime. Id. The third aggravating factor, the first two mitigating factors, and the ultimate recommendation call for evaluative judgments that differ appreciably from those required at the guilt-innocence phase of most criminal proceedings. And a jury that knows it will probably have the final say on such issues may react very differently from one that thinks it is merely offering advice to the trial court.

129 This is due partly to the nature of the beast, see McCleskey $v$ Kemp, 481 US 279 (1987) (rejecting an elaborate statistical challenge to Georgia's imposition of the death penalty and emphasizing the role of individualized discretion in imposing the death sentence), and partly to the Supreme Court's disapproval of a more categorical approach. See, for example, Eddings $v$ Oklahoma, 455 US 104 (1982) (holding that sentencing juries and judges must consider individual mitigating circumstances); and Sumner $v$ Shuman, 483 US 66 (1987) (rejecting mandatory death sentences for murders committed by those serving life terms). 
clarity and hardness. To the extent that the determination is overtly evaluative and judgmental, any defaulted claim that is not constitutionally harmless would have a "reasonable possibility" of affecting the reliability of the sentence of death.

Of course, that is not inevitably so. The defaulted claim might concern an issue that is no more indeterminate and judgmental than the factual conclusions that typically underlie a guilty verdict. But in general, the concept of "reasonable possibility" of factual error would have a broader reach in capital cases because of the broader range of facts relevant to the imposition of a capital sentence. In other words, for defaulted claims with respect to death sentences, we would expect the difference between an outcome-based construction of "prejudice" and one oriented toward the factual reliability of the underlying findings to be relatively insignificant. Both standards are likely to converge on the traditional concept of harmless error.

Though our approach is generally favorable to capital defendants, it would not aggravate the problem that seems to bother some of the Justices - the long, drawn-out nature of litigation in capital cases. That problem arises not from defaulted claims, but from repetitious habeas petitions. Any legal change that would encourage defendants to collapse all possible claims into one habeas petition, and thereby allow courts to resolve all merits issues at once, would reduce that problem. We think that that is exactly the effect of our proposal, since it would tend to lead directly to a merits decision on all available claims.

\section{SOME BroAder IMPLicATIONS}

Our discussion of procedurally defaulted claims is now at an end. The argument need not be carried further, as it is possible to simplify and, we think, to improve the law of defaulted claims without affecting the rest of the habeas landscape. At the same time, our argument does cast a shadow on at least two other important habeas issues: (1) the proper standards for purely factual ineffective assistance of counsel claims; and (2) the proper standards for claims of constitutionally insufficient evidence. We do not treat these issues exhaustively, because the concerns they raise are different from those raised by defaulted claims and merit fuller treatment than is possible here. What follows is therefore brief and somewhat speculative. 


\section{A. Factual Ineffective Assistance Claims}

Most ineffective assistance claims are not based on the defense counsel's failure to raise a federal claim or defense. More commonly, the allegation of ineffectiveness concerns a decision that affected the development of the facts-for example, failure to offer an alibi or character witness or to uncover and present other exculpatory evidence. Such cases are in some ways like the allegation of ineffectiveness based on defaults of federal claims. In both instances, the defendant argues that, through no fault of his own, some claim or evidence was not properly presented. The law of defaulted claims seeks to sift through such arguments to identify injustices that require habeas relief. In our view, ineffective assistance doctrine should have the same aim in factual error cases.

This last step is quite controversial. The conventional wisdom, among both judges and academics, is that a claim of ineffective assistance of counsel goes not to the substance of the conviction, but to the process by which it was obtained. ${ }^{130}$ Consequently, the argument goes, such claims should be granted regardless of the nature of the attorney error in question-essentially the position adopted in Kimmelman $v$ Morrison.

In our view, this process-oriented approach to ineffectiveness is flawed for the same reasons that argue against federal habeas review of defaulted Fourth Amendment claims. Consider, for example, a defendant who tells his lawyer that he wants to testify on his own behalf. The lawyer responds with a simple, "Fine with me," and neither dissuades the defendant from testifying nor warns him of the attendant risks. The defendant then takes the stand and testifies that he was in another place at the time of the crime. On cross-examination the prosecutor shreds his story, forcing him to admit that his direct testimony was false. Predictably, the jury convicts.

Even if the defense counsel made no other error, one could argue that the defendant was convicted in part because of his lawyer's incompetence in failing to make him aware of the risks of

\footnotetext{
150 See, for example, LaFave and Israel, 2 Criminal Procedure $\S 11.10$ at 50 (Supp 1989) (cited in note 39)(criticizing the argument that ineffective assistance doctrine should focus exclusively on outcome effects that bear on the defendant's guilt); Berger, 86 Colum L Rev at 94 (cited in note 20)(arguing that the "prejudice" prong of Strickland should be abandoned because the constitutional protection concerns the process of effective representation, without regard to its effects); and Goodpaster, 14 NYU Rev L \& Soc Change at 68-70 (cited in note 20)(arguing that ineffective assistance doctrine must protect the entire process, not merely determination of guilt, on the ground that the adversary system serves multiple functions).
} 
waiving his Fifth Amendment privilege. Yet, even assuming that incompetence can be shown, it is not so clear why relief should be granted. The defendant fared worse than he might have, in that a better lawyer might have gotten him off, but the error does not cast doubt on the reliability of the determination of guilt. The problem here seems to us very much like the situation in Kimmelman, and our response might well be the same. ${ }^{131}$

One is left with the argument that this hypothetical defendant should get relief on the ground that effective assistance of counsel is not an aid to accurate results but an end in itself. This proposition may be the implicit premise of those who maintain that guilt and innocence should be irrelevant to assessing ineffectiveness. But it is hard to see why counsel should be viewed as an end rather than a means. Counsel, after all, is part of a larger adjudicative process, and the entire process is short-circuited whenever the defendant pleads guilty. The fact that this happens in the majority of cases $^{132}$ suggests that our attachment to the process as an end in itself is, at best, half-hearted. Unless disposition of criminal prosecution by guilty plea is necessarily and inherently wrong, ${ }^{133}$ it is hard to escape the conclusion that the trial process-including effective assistance of counsel-is a tool for reaching right results and not an end in itself.

On that view, factual ineffectiveness claims present a classic ex ante/ex post problem. Ex ante, adequate representation across the board is required so that innocent defendants (or merely arguably

\footnotetext{
131 One might argue that the defendant should have a viable Fifth Amendment claim on the ground that his waiver was not sufficiently "knowing" and "intelligent." This argument is a hard one to make out, however, given that defendants regularly waive the privilege without legal advice of any sort in the police station, and such waivers are not thought to raise constitutional problems. See, for example, Moran v Burbine, 475 US 612 (1986). Nor can one distinguish police station waivers from courtroom waivers based on their practical consequences: the likeliest consequence of a confession in the police station, as in the courtroom, is conviction. For the classic exposition of this point, see Yale Kamisar, Equal Justice in the Gatehouses and Mansions of Criminal Procedure: From Powell to Gideon, from Escobedo to ... , in A.E. Dick Howard, ed, Criminal Justice in Our Time 1, 9-25 (U Virginia, 1965).

${ }^{132}$ Estimates vary, but all agree that more than half of all prosecutions are resolved by guilty pleas. See, for example, Yale Kamisar, Wayne R. LaFave, and Jerold H. Israel, Modern Criminal Procedure 17 (West, 7th ed 1990) (estimating that guilty pleas dispose of 7090 percent of felony cases not dismissed); and Michael O. Finkelstein, A Statistical Analysis of Guilty Plea Practices in the Federal Courts, 89 Harv L Rev 293, 313 (1975) (reporting guilty plea data from selected federal districts from 1970-74 which show that more than half of all cases not dismissed were terminated by guilty pleas).

${ }^{183}$ That is, apart from inducements offered by the government to secure the plea. Many persons think that plea bargaining is normatively unacceptable, but few assert that disposition by plea is itself unacceptable.
} 
innocent defendants) can successfully defend the charges against them. In other words, one cannot deny counsel to guilty defendants while granting counsel to innocent ones, because it is impossible to tell them apart in advance of trial. Ex post, however, it is sometimes possible to separate cases where lawyer error raises a "reasonable possibility" of injustice from cases where it does not. The defendant whose lawyer failed to prevent the client's false (and damning) testimony falls into the latter category. Arguably, relief should not be granted in such a case.

In short, the argument for applying a unitary innocencerelated prejudice standard in this context is the same as the argument for applying such a standard to defaulted claims. If the law's goal is to respect the states' interests in finality by denying relief in most cases, while correcting cases of real injustice, the courts should focus directly on the risk of injustice when deciding whether to grant relief. That is why we have proposed a simple prejudice test for defaulted claims. The same reasoning applies to other attorney errors as well. If an alibi witness suggests that the defendant may be innocent, the defendant deserves relief no matter how negligent or reasonable was his attorney's decision not to call that witness. By the same token, if the witness's testimony shows nothing of consequence, it should make no difference whether, given the information available to counsel at the time, the decision not to call the witness was or was not grossly negligent. If preventing unjust punishment is the goal, an innocence-related prejudice standard is both a necessary and sufficient means of achieving it.

Yet simply abolishing the performance prong of Strickland for all cases would raise serious practical problems. Anytime a criminal defendant loses his case at trial, he can point to a long list of evidentiary decisions by counsel that could have been made differently. Every choice to investigate (or not investigate) a defense or argument, to interview (or not interview) a potential witness, or to ask (or not ask) a question at trial can be second-guessed. A sound ineffective assistance doctrine must weed out the mass of such claims, yet preserve relief for those defendants who most deserve it. The system cannot afford to examine closely the impact of the lawyer's every action on the factual record.

Unfortunately, the screening process is a good deal harder in cases of factual error than in cases involving defaulted claims. First, while the list of legally plausible defaulted claims in any given case must be fairly short, the list of evidentiary decisions is very long indeed. Second, a large portion (probably a majority) of 
defaulted claims can quickly be categorized as irrelevant to the justice of the defendant's conviction. That is because many constitutional claims-including virtually all Fourth and Fifth Amendment claims-do not bear on the question whether the defendant in fact committed the crime charged.

Factual errors by defense counsel are different. Most evidentiary decisions by lawyers do bear on guilt or innocence, for the simple reason that only evidence relevant to that issue can be introduced at trial. For every criminal trial that generates a conviction, the defendant can point to a host of evidentiary decisions by his lawyer that, with hindsight, might conceivably have affected the accuracy of the guilty verdict.

One can plausibly defend the performance prong as a convenient device for screening such claims. It may be easier to dispose quickly of many ineffective assistance claims on the ground that the attorney decisions at issue were within the range of competent lawyering than to look into the likelihood that the relevant decisions undermine one's faith in the outcomes. (But perhaps not; the answer is not obvious.) Note, however, what that rationale implies about the purpose of the inquiry into attorney performance. That inquiry may be useful, but not because attorney performance is particularly important in itself. Instead, the performance prong makes sense, if at all, as a rough proxy for prejudice-that is, as a way of screening out those cases where a prejudice inquiry would be costly, and in any event would probably result in a denial of relief.

No such proxy is needed in cases of defaulted claims, and for those cases the performance prong therefore should be discarded. Indeed, a separate doctrine of ineffective assistance is unnecessary in that context; a single doctrine for procedural defaults should suffice. Whether the proxy is useful in purely factual cases depends on whether it is an effective proxy-whether a focus on lawyer performance reaches substantially the same results as would a focus on prejudice. That is a hard question. But even if the performance prong should remain intact, it is worthwhile to focus judicial attention on that prong's ultimate purpose of promoting fair outcomes, and not on process for process's sake.

\section{B. Sufficiency-of-the-Evidence Claims}

Sufficiency-of-the-evidence review raises the question of how far the system should (or can) go to protect innocence. Since we have argued for innocence-protective review in the context of defaulted claims, one might fairly ask how we would apply our ap- 
proach when a claim of innocence is not tied to any direct claim of constitutional error.

Consider two cases. In the first, the defendant seeks to compel the government to disclose certain witness statements prior to trial, on the ground that the statements might suggest that someone other than the defendant committed the crime in question. The trial court, after reviewing the witness statements, denies the defendant's motion, and the defendant is convicted. The defendant fails to raise the discovery claim on direct appeal, thus triggering a state-law procedural bar. On federal habeas, he seeks to resurrect the discovery claim, and the habeas court concludes that had the evidence in question been disclosed, the defendant reasonably might have been acquitted. If the court were to apply our proposed standard, it would vacate the conviction and order a new trial. ${ }^{134}$

In the second case, the trial court decides in advance of trial, correctly, that the evidence must be disclosed. Defense counsel then uses the witness statements skillfully at trial, marshalling the evidence to show that the government may have prosecuted the wrong person. Inexplicably, the jury convicts. The trial court denies the defendant's motion to set aside the verdict and the conviction is affirmed on appeal. On federal habeas, the defendant argues not that his trial or appeal were constitutionally flawed in some procedural sense, nor that his counsel was incompetent, but simply that he is innocent-that the system got his case wrong. Under Jackson $v$ Virginia, the defendant is entitled to relief if the habeas court finds that no rational jury could have found guilt beyond a reasonable doubt. ${ }^{135}$ While this standard sounds hard to meet in the abstract, in practice it is even harder: simple insufficiency-ofthe-evidence relief on federal habeas is almost unheard of.

If our argument about defaulted claims is right, then the insufficient evidence claim should receive a more favorable hearing. The defendant's claim of injustice is essentially the same in both situations. And, one might contend, there is no obvious reason to grant relief to arguably innocent defendants who happen to have constitutional claims, but to deny relief to arguably innocent defendants who are victims of factfinder error. An innocenceprotective law for defaulted claims, such as our proposal, seems to

\footnotetext{
134 This hypothetical is derived from Carrier, 477 US 478 . We have added the additional facts (which may or may not have been true in Carrier) that the undisclosed evidence was exculpatory in suggesting a misidentification, and that nondisclosure thus prejudiced the defendant.

135443 US 307 (1979).
} 
lead logically to the position that habeas courts should regularly and strictly review the sufficiency of the evidence supporting state convictions. If this conclusion is accurate, our argument has more radical implications for habeas corpus than we have acknowledged.

This point is at least partly true. It is wrong to worry a great deal about protecting innocence in the first hypothetical, but not at all in the second. To that extent, our argument does imply that habeas courts should take seriously (more so than they probably now do) claims of insufficient evidence. But Jackson suggests as much. The rarity with which such claims are granted in federal habeas may indicate that current practice is not consonant with Jackson's promise. This may be because habeas doctrine concentrates on purely procedural issues-issues that may have the effect of drowning out less "legal" claims that go directly to the justice of the defendant's conviction. If so, reforming the law of defaulted claims along the lines we have suggested would facilitate more serious review of Jackson claims by simplifying the process of getting to the merits.

Having said that, we also think that habeas courts should undertake sufficiency-of-the-evidence review in a very deferential manner. This position is not at odds with a less deferential prejudice standard for defaulted claims. Sufficiency-of-theevidence review simply allows another decisionmaker to secondguess the conclusion reached earlier on the same facts. In deciding what standard to apply to such claims, there is no good reason to prefer the bottom-line judgment of the second decisionmaker to that of the first, given a constant record. Indeed, the opposite is true. The jury that heard the case, complete with live testimony, was in a better position to assess the evidence than subsequent decisionmakers. The jury's judgment should be accorded substantial deference, particularly when state appellate courts have affirmed that judgment.

The analysis changes when a constitutional claim (other than the Jackson insufficiency claim) is involved. Deference to the factfinder should recede when the jury's judgment was based on an incomplete record, as when the prosecution failed to disclose exculpatory evidence prior to trial. Deference is also less appropriate in cases like Teague, where the jury was selected in a manner that might bias it in the government's favor. These examples show that the presence or absence of a defaulted constitutional claim may not be irrelevant to the defendant's claim of innocence, but instead is sometimes a strong piece of evidence supporting that claim. At least that is so when the constitutional claim in some way suggests 
that the outcome was unjust. The presence of a constitutional issue should therefore be a significant factor-albeit not an essential one-in evaluating the defendant's.claim of innocence.

\section{ConCLUSION}

The doctrine that governs disposition of defaulted claims on federal habeas corpus is needlessly complex, and does not clearly serve any sensible policy of collateral review. We have argued for two complementary reforms. First, the concept of "prejudice," under both Wainwright $v$ Sykes and Strickland $v$ Washington, should be narrowed to include only outcome effects that create a "reasonable possibility" of factually erroneous conviction (or sentence of death). Second, the Sykes requirement of "cause" for procedural default and the analogous and intersecting Strickland requirement that attorney error reflect incompetence should be ignored. When a default raises a "reasonable possibility" of unjust outcome, relief should be granted without regard to the "cause" or competence categorization of the error. This approach would allow courts to grant relief where it is most justified and deny relief where it is not warranted. Equally important, it would foster simplicity and rationality, qualities sorely lacking in the current law.

The temptation at this point is to suggest that our argument implies a much broader and deeper reform of habeas law, going far beyond the law of defaulted claims. We might find such a reform congenial. But defaulted claim cases raise unique problems, and the analysis of such claims may not be transferable to other contexts. Because defaulted claims arise infrequently and unpredictably, the deterrence argument for relief in such cases is weak. That may not be true for non-defaulted claims. Similarly, because the list of potential defaulted claims in any one case is small or nonexistent (and usually consists of non-guilt-related claims), applying a unitary prejudice standard such as the one we propose should prove workable. That may not be so for other ineffective assistance claims, where the list of potential attorney "errors" in any given case is very long indeed.

Thus, the reform we urge is not especially far-reaching. It is an effort to rectify a fairly small problem of habeas administration that has received far more judicial time and energy than it deserves, in the process generating noticeably inequitable results. This may be one of those rare opportunities to improve the caliber of justice offered by our system, without the heavy adjudication costs such improvements usually entail. If so, it is an opportunity that our criminal justice system can hardly afford to abandon. 